\title{
New species and records of Caulleriella (Annelida, Cirratulidae) from shelf and slope depths of the Western North Atlantic Ocean
}

\author{
JAMES A. BLAKE ${ }^{1,2}$ \\ ${ }^{1}$ Aquatic Research \& Consulting, 24 Hitty Tom Road, Duxbury, MA 02332. USA. \\ ${ }^{2}$ Department of Invertebrate Zoology, Museum of Comparative Zoology, Harvard University, 26 Oxford Street, Cambridge, MA 02138 \\ USA. \\ ఏ"jablake9@gmail.com; @ https://orcid.org/0000-0001-8217-9769
}

\begin{abstract}
Six species of Caulleriella (Cirratulidae), four new to science, are reported from continental shelf and slope depths of the western North Atlantic. The majority of new material was collected as part of deep-water reconnaissance and monitoring surveys along the U.S. Atlantic coast from New England to the Carolinas that were intended to understand the potential impacts of oil and gas exploration in poorly known offshore environments. Additional materials from shallow water and shelf habitats off New England and New York as part of other projects are also included. New species include: Caulleriella filiformia n. sp., C. nobska n. sp., C. pintada n. sp., and C. rodmani n. sp. In addition, new records and comments are provided for $C$. venefica Doner \& Blake, 2016 a widespread shelf species and $C$. sp., a potential new species represented by a few specimens from rocky nearshore New England habitats. The latter may be related to the enigmatic $C$. fragilis (Leidy, 1855). A review of known deep-water species of Caulleriella is provided.
\end{abstract}

Key words: Annelida, benthos, new species, New England, Delaware, New Jersey, North Carolina, South Carolina

\section{Introduction}

Cirratulid polychaetes are typically the dominant species of nearshore benthic communities along continental margins and also in some deep-sea locations. Cirratulids are classified and organized into bitentaculate and multitentaculate genera. While the multitentaculates are common in intertidal and nearshore shelf habitats, they are rare in deep water. In contrast, the bitentaculates are widespread in all habitats including the deep sea (Blake \& Magalhães 2019). Recent studies have reported new species of Cirratulidae, mostly bitentaculates, from the Caribbean Sea, South America, the Southern Ocean and Antarctica, the Pacific Ocean, and Southeast Asia (Blake 1996, 2006, 2015, 2016, 2018, 2019; Blake \& Dean 2019; Doner \& Blake 2006; Elías \& Rivero 2009, 2011; Magalhães \& Brock 2013). Several of these studies are from offshore deep-water surveys.

In the present study bitentaculate cirratulids of the genus Caulleriella Chamberlin, 1919 are reported from reconnaissance and monitoring surveys along the U.S. Atlantic coast from New England to the Carolinas. Four new species of Caulleriella are described; three are from deep-sea continental slope habitats off the U.S Atlantic coast and one is from nearshore benthos in New England. In addition, new records and morphological details are recorded for C. venefica Doner \& Blake, 2006 from nearshore and shelf habitats.

\section{Materials and methods}

Materials examined as part of this study. The majority of specimens examined as part of this study were collected by the author and colleagues as part of offshore surveys funded by the U.S. Department of the Interior's former Minerals Management Service (MMS), now the Bureau of Ocean Energy Management (BOEM), during the 1980s. These studies were intended to evaluate the potential impact of oil and gas exploration and development on Georges 
Bank off New England (1981-1985) and along the U.S. Atlantic Continental Slope and Rise (ACSAR) from the Canadian boundary to the Carolinas (1983-1987).

Additional samples from the northeastern United States from Massachusetts to New Jersey accumulated from various local collections or environmental surveys are also included. All MMS collections are deposited in the National Museum of Natural History, Smithsonian Institution (USNM). Other collections are deposited in Museum of Comparative Zoology (MCZ), Harvard University.

The MMS samples were collected using 300- $\mu \mathrm{m}$-mesh sieves. These fine-mesh sieves resulted in the retention of fragile threadlike specimens from deep-water that otherwise would have been lost or damaged.

Morphological observations. Specimens were examined using a Wild M-5 stereomicroscope and a Zeiss RA research microscope equipped with phase contrast optics. Photomicrographs were taken with a Nikon D7100 camera mounted on both the stereo- and compound microscopes. For observation, specimens were first stained with an aqueous solution of Shirlastain A to highlight difficult-to-see surficial morphology. Some specimens were stained with a saturated solution of Methyl Green (MG) in 70\% ethyl alcohol (ETOH) in order to identify staining patterns of subdermal glands evident on some species. Line drawings were first sketched in pencil using a drawing tube or camera lucida on the Zeiss RA and later transferred to Dura-Lar ${ }^{\circledR}$ matte film and inked.

Additional specimens were prepared for scanning electron microscopy (SEM) by dehydration in an ascending ETOH series of 70-95\% for 10 min each, followed by three changes of $100 \%$ ETOH for 15 min each. Specimens were critically point dried with a Samdri 795 Critical Point Dryer, mounted on aluminum stubs, coated with gold using an EMS-550 Sputter coater, and viewed with a Hitachi S-2460N SEM or FEI Quanta 250 SEM at Hofstra University in Dr. Jason Williams' laboratory.

Abbreviations used on figures: anC, anal cirrus; br, branchiae; dCr, dorsal crest; dT, dorsal tentacle; eso, esophagus; int, intestine; mo, mouth; neP, neuropodia; noP, notopodia; nuO, nuchal organ; per, peristomium; phrx, pharynx; pr, prostomium; prob, proboscis; pyg, pygidium; Set, setiger; vGr, ventral groove.

\section{Results}

\section{Family Cirratulidae Ryckholt, 1851}

Diagnosis. Body elongate with numerous short segments; not divided into distinct regions but anterior and/or posterior segments sometimes expanded and crowded. Prostomium narrow and conical or broad and wedge shaped, without appendages; eyespots present or absent; paired dorsolateral nuchal organs present. Peristomium achaetous, smooth or with two or more distinct annuli. Grooved dorsal tentacles arise as a single pair or as multiple groups of filaments on posterior margin of peristomium or on one or more anterior setigerous segments. Branchiae long, filamentous, usually occurring over numerous segments. Parapodia biramous with rudimentary podial lobes. Setae simple, including capillaries, acicular spines or bidentate hooks. Pygidium a simple lobe sometimes with sub-anal disk, or terminal cirri. Pharynx ventral, unarmed. Sexual and asexual reproduction may occur.

\section{Genus Caulleriella Chamberlin, 1919}

Type species: Cirratulus viridis Langerhans, 1881. Original designation by Chamberlin 1919.

Diagnosis. (after Blake \& Magalhães 2019). Prostomium elongate, conical to pointed; peristomium elongated to short, dorsal tentacles usually beginning anterior to setiger 1 . Middle body segments not beaded; parapodia often with noto- and neuropodia widely separated laterally. Modified setae including capillaries and bidentate, crotchetlike hooks, not arranged into modified cinctures. In some species, unidentate hooks may occur in some regions of the body in addition to bidentate hooks. Pygidium either a simple conical lobe or with one or two anal cirri.

Remarks. To date, approximately 45 species of Caulleriella are known (Read \& Fauchald 2020; Blake \& Magalhães 2019). The current definition of the genus essentially dates from Blake (1996), who, among other things, determined that in addition to having bidentate hooks, most species of Caulleriella differ from other bitentaculate 
cirratulids in having the noto- and neuropodia widely separated from one another along the body; this generalization, however, does not hold up in species that have long, narrow threadlike bodies.

Bidentate hooks. Three types of bidentate hooks have been reported for species of Caulleriella. (1) One type is a typical bidentate crotchet, found in most species, where the apical tooth appears to emerge directly from the end of shaft with no hood or flange along the shaft. This type of hook is characteristic of most species. (2) A second type of hook has a hood or flange on the convex side of the shaft that extends apically forming the apical tooth. This type of seta was first described for C. alata by Southern (1914). Although not stated, Southern's name for the species appears to be derived from alatus, Latin for winged and refers directly to the transparent hood on the convex side of the shaft that merges with the apical tooth. These 'alate' hooks have been reported in nine species of Caulleriella (see list in Discussion section) and likely occur in others where details of the bidentate teeth are not well described. (3) A third type of hook has a transparent hood that extends from the main fang to the concave side of the shaft, similar to hoods found in some spionids and paraonids. This type of hook is only known from C. bathytata Blake, 2019 an abyssal species from the Pacific Ocean.

The nature of the 'alate' hooks is not well understood. There is some evidence that the so-called hood or flange on the convex side of the shaft is actually an artifact of the shaft having a groove on the lateral or convex side and that a change in thickness along the shaft produces a lighter or more transparent area that is the 'hood' observed in light microscopy. Likewise, details of 'alate' hooks suggest that the apical tooth may actually be a projecting ridge or an extension of the shaft that only appears as a tooth when observed in lateral view. Caulleriella kacyae Blake, 2018 from the Weddell Sea, Antarctica has a broad accessory sheath on the convex side of the shaft that terminates on the tip of the shaft as a ridge above the main fang; in some views this sheath appears to be divided producing a tridentate appearance (Blake 2018). The 'alate' bidentate hooks of C. pacifica E. Berkeley, 1929 were illustrated with SEM by Magalhães \& Bailey-Brock (2015). The convex side of the curved shaft has a distinct channel or groove that could appear as the hood in light microscopy at certain angles. In addition, the apical tooth is short and appears to be a low ridge. In contrast the SEMs of the bidentate hooks of $C$. venefica Doner \& Blake, 2006 (see Figure 8 in $C$. venefica section below) show no evidence of a groove along the shaft and the apical tooth is narrow and pointed. These observations suggest that an in-depth investigation of these hooks may yield additional characters useful in species delimitation.

Parapodia. Most species of Caulleriella have the noto- and neuropodia widely separated along the body (Blake 1996; Blake \& Magalhães 2019); in some species such C. quadrata Blake \& Dean, 2019, the podia are so widely separated they appear at four corners of the body when viewed in cross section (Blake \& Dean 2019). This generalization, however, is not as obvious in deep-water species where the bodies are long and thin; however, even in these taxa, the podial lobes are distinctly separated from one another rather than being close as in species of Tharyx.

Bathymetry. Recent studies have added numerous new species of Caulleriella and expanded descriptions of others (Blake 2018, 2019; Blake \& Dean 2019). However, only five of the 45 previously known species of Caulleriella, four from around Antarctica and one from the abyssal Pacific, are known from depths of $500 \mathrm{~m}$ or greater (Blake 2018, 2019): C. antarctica (Hartman, 1978) (1120 m), C. bathytata Blake, 2019 (4877 m), C. eltaninae Blake, 2018 (870 m), C. fimbriata Blake, 2018, (1884 m), and C. kacyae Blake, 2018 (1035 m). Three additional deepwater and one shallow water species of Caulleriella are newly described in the present study bringing the number of known species for the genus to 49 of which only eight occur in deep water. Additional records and descriptive comments for Caulleriella venefica, a widespread nearshore and continental shelf species along the U.S. Atlantic coast, are also provided. In addition several specimens of an additional small species of Caulleriella, are reported from rocky habitats in Cape Cod Bay. These specimens are not named but may be conspecific with or related to $C$. fragilis (Leidy, 1855), which has not been described since the original report. The following species are treated in this study.

1. Caulleriella filiformia $\mathbf{n}$. sp.

2. Caulleriella nobska $\mathbf{n}$. sp.

3. Caulleriella pintada $\mathbf{n}$. sp.

4. Caulleriella rodmani $\mathbf{n}$. sp.

5. Caulleriella venefica Doner \& Blake, 2006

6. Caulleriella sp. 


\section{Caulleriella filiformia new species}

Figures 1-2

urn:Isid:zoobank.org:act:263E4535-116F-490F-8ABC-0726725F0F29

Caulleriella sp. B: Maciolek et al. 1987a: D-2 (in part); 1987b: D-2 (in part); Hilbig 1994: 940 (in part)

Caulleriella sp. 3: Blake et al. 1987: C-2 (in part); Hilbig 1994: 940 (in part).

Material examined. (48 specimens) Southeastern USA, off Charleston, South Carolina, U.S. South ACSAR Program, coll. J.A. Blake, Chief Scientist. Sta. 15: Cruise SA-5, Rep. 2, 18 Sep 1985, 32 $11.99^{\prime} \mathrm{N}, 7^{\circ} 42.23^{\prime} \mathrm{W}$, 1991 m, holotype (USNM 1642576); Rep. 1, 18 Sep 1985, 32 ${ }^{\circ} 12.00^{\prime} \mathrm{N}, 76^{\circ} 42.23^{\prime} \mathrm{W}, 1988 \mathrm{~m}, 2$ paratypes (USNM 1642575); Rep. 3, 18 Sep 1985, 32 $11.97^{\prime} \mathrm{N}, 7^{\circ} 42.24^{\prime} \mathrm{W}, 1991 \mathrm{~m}, 1$ paratype (USNM 1642577); Cruise SA-4, Rep. 1, 16 May $1985,32^{\circ} 12.02^{\prime} \mathrm{N}, 7^{\circ} 42.18^{\prime} \mathrm{W}, 1993 \mathrm{~m}, 1$ paratype (USNM 1642572); Rep. 2, 16 May 1985, $32^{\circ} 12.05^{\prime} \mathrm{N}, 76^{\circ} 42.18^{\prime} \mathrm{W}, 1991 \mathrm{~m}, 4$ paratypes (USNM 1642573); Rep. 3, 16 May, 1985, 32 $10.74^{\prime} \mathrm{N}, 7^{\circ} 42.93^{\prime} \mathrm{W}$, 2003 m, 2 paratypes (USNM 1642574)._-Off New England, U.S. North Atlantic ACSAR Program, coll. G.W. Hampson, Chief Scientist. Sta. 5: Cruise NA3, Rep. 1, 04 Jul 1985, 4005.11'N, 67²9.84’W, 2058 m, (3, USNM 1642578); Cruise NA4, Rep 2, 25 Nov 1986, 4005.09’N, 67²9.84’W, 2071 m (2, USNM 1642579); Rep. 3, 25 Nov $1985,40^{\circ} 05.07^{\prime} \mathrm{N}, 67^{\circ} 29.81^{\prime} \mathrm{W}, 2071 \mathrm{~m}$ (1, USNM 1642580); Cruise NA5, Rep. 1, 29 Apr 1986, 4005.06’ $\mathrm{N}$, $67^{\circ} 29.94^{\prime} \mathrm{W}, 2052 \mathrm{~m}$ (2, USNM 1642581); Rep. 3, 29 Apr 1986, 4005'.01’ N, 67²9.90’W, 2085 m (2, USNM 1642582); Cruise NA6, Rep. 1, 26 Jul 1986, 4005.07’N, 67²9.08’W, 2063 m (1, USNM 1642583); Rep. 3,26 Jul $1986,40^{\circ} 05.09^{\prime} \mathrm{N}, 6^{\circ} 29.67^{\prime} \mathrm{W}, 2055 \mathrm{~m}$ (1, USNM 1642584). Sta. 6: Cruise NA2, Rep. 1, 29 Apr 1985, 4005.04’ $\mathrm{N}$,

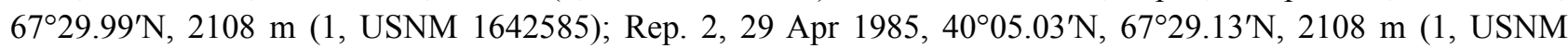

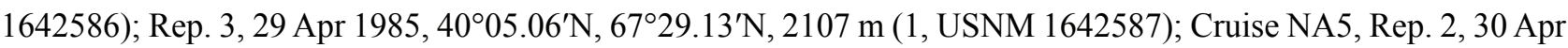

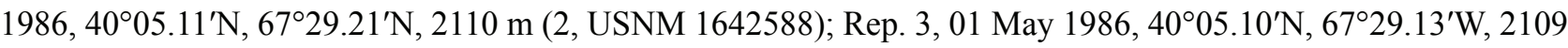
m (1, USNM 1642589). Sta. 8: Cruise NA2, Rep. 1, 28 Apr 1985, 40¹0.24’N , 67³7.16’W, 2185 m (1, USNM

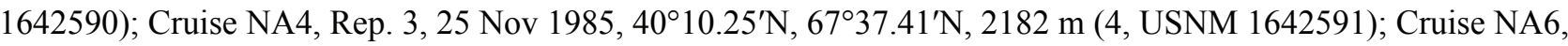

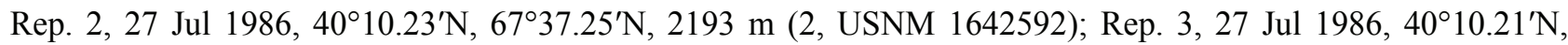

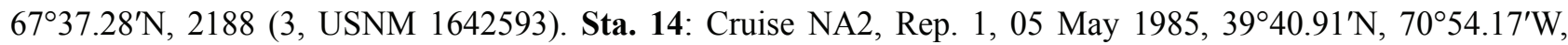
2095 m (4, USNM 1642594); Rep. 2, 5 May 1985, 3940.93’N, 7054.21’ W, 2092 m (1, USNM 1642595). Sta. 15: Cruise NA2, Sta. 15, Rep. 2, 5 May 1985, 3940.07’N , 7054.27’W, 2145 m (1, USNM 1642596); Rep. 3,6 May $1985,39^{\circ} 40.10^{\prime} \mathrm{N}, 70^{\circ} 54.31^{\prime} \mathrm{W}, 2140$ m. (1, USNM 1642597). - Off New Jersey and Delaware, U.S. MidAtlantic ACSAR, Program, coll. R. Petrecca, Chief Scientist. Mid-6, Sta. 2: Rep. 3, 13 Nov 1985, 38³5'.83'N, 7253.91'W, 1994 (3, USNM 1642598).-COff New Jersey, U.S. EPA DWD-106 Site Survey, R. Petrecca, Chief Scientist: Sta. G, Rep. 3, 18 Nov 1985, 3855.60’ N, 7202.62'W, 2509 m (1, MCZ 161720).

Description. A long, thin, threadlike species (Figs. 1A-C, 2A, C-E); holotype complete, $9.1 \mathrm{~mm}$ long, $0.16 \mathrm{~mm}$ across anterior segments and $0.12 \mathrm{~mm}$ across far posterior segments, for 58 setigers; one complete paratype (USNM 1642576), $8 \mathrm{~mm}$ long for 60 setigers. Body generally cylindrical throughout, with no evidence of dorsal or ventral grooves. All segments moniliform to some extent (Fig. 2A, C-F); 5-8 anteriormost setigers relatively short, constituting thoracic region (Figs. 1A-B, 2A-B), about 1.5-2.0 times as wide as long, then segments becoming longer, about 1.5 times as long as wide (Fig. 1A, 2A, C-E); posterior segments becoming shorter, rounded, about as long as wide, weakly moniliform (Figs. 1C, 2F), continuing to pygidium bearing two narrow anal cirri (Figs. 1A, 2F-G). Individual segments along most of body transparent, with intestinal track and coelom clearly apparent (Fig. 2A-F); heart body evident in anteriormost segments of some specimens; epidermis of anterior and middle body segments lumpy, but not producing transverse annulations. Color in alcohol opaque white, with no pigment apparent on body.

Pre-setiger region narrow, about 2.3 times as long as wide, about as long as first four setigers (Figs. 1A-B, 2A-B). Prostomium triangular, tapering to narrow rounded apex (Fig. 1A-B); eyespots absent; nuchal organs not observed. Peristomium elongate, narrow, with weak lateral grooves in anterior one-third, not producing annular rings (Figs. 1A, 2A); holotype with grooves producing lateral pockets (Fig. 1B). Dorsal tentacles widely spaced, arising from near posterior border of peristomium (Fig. 1A-B); first pair of branchiae arising immediately posterior to dorsal tentacles on peristomium; second pair of branchiae arising on posterior border of setiger 1 , dorsal to notosetae (Fig. 1A-B). Subsequent segments with branchiae in similar position; branchiae long, thin, present along most of body to near posterior end.

Parapodia reduced; anterior segments with weakly developed podial lobes from which setae arise. Noto- and neuropodial setal fascicles distinctly separated from one another anteriorly, becoming widely separated from one 
another in middle and posterior setigers. Noto- and neurosetae of anteriormost setigers with 5-8 long capillaries per fascicle; notoacicular bidentate hooks first present from setigers 7-10 (setiger 8 in holotype); neuroacicular hooks similar in distribution (beginning setiger 7 in holotype). Hooks mostly replacing capillaries, 1-3 per fascicle at first, increasing to 4-5 in middle and posterior segments, reduced to $1-3$ in far posterior segments. Hooks with a thick, slightly curved shaft tapering to thick main fang surmounted by a thin apical tooth as an extension of an 'alate' flange on convex side of shaft (Figs. 1D-E, 2H-I); neuropodial hooks shorter and thicker (Fig. 1D) than notopodial hooks (Fig. 1E). Hooks of far posterior segments becoming longer, less curved, prominently visible on segments anterior to pygidium.

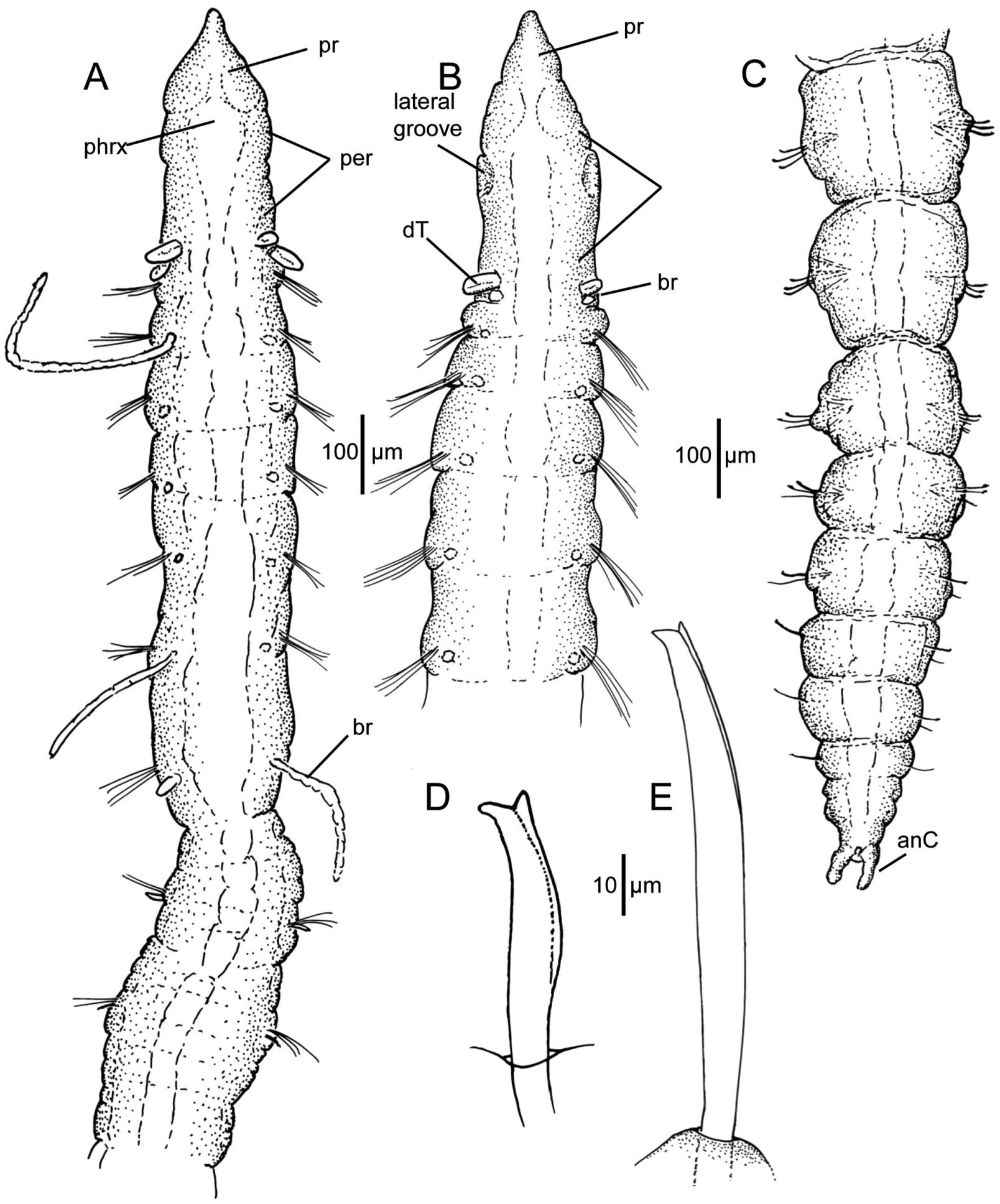

FIGURE 1. Caulleriella filiformia n. sp. Paratype (USNM 1642572); A, anterior end, dorsal view: Holotype (USNM 1642576): $\mathrm{B}$, anterior end, dorsal view; C, posterior end, dorsal view; D, neuropodial hook; E, notopodial hook. 

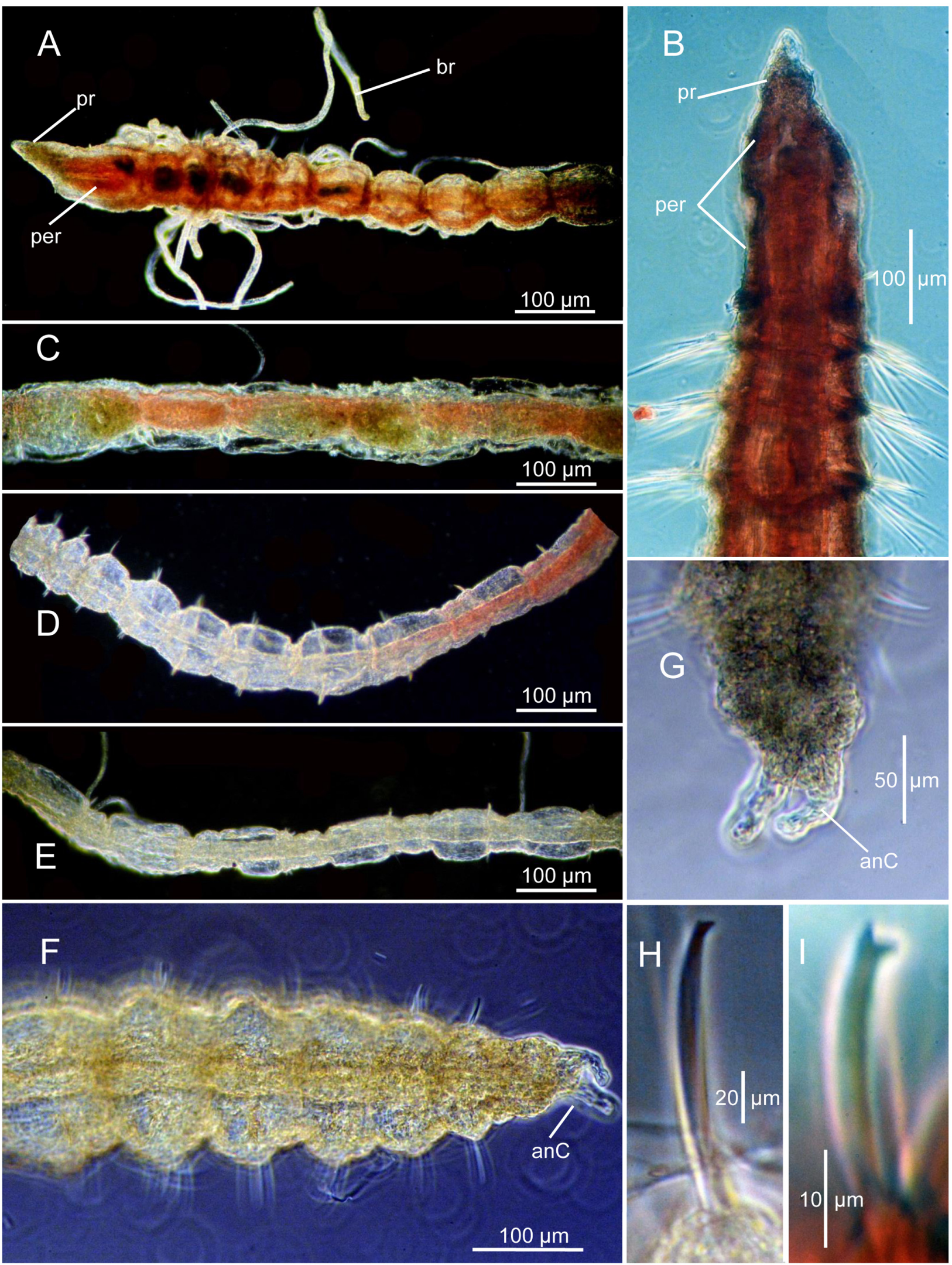

FIGURE 2. Caulleriella filiformia n. sp. A, Anterior end, left lateral view; B, Anterior end, dorsal view; C, mid-body setigers, dorsal view; D, transition from mid-body to posterior setigers, dorsal view; E, posterior setigers, dorsal view; F, far posterior setigers with pygidium; G, pygidium dorsal, view; H, notopodial hook; I, neuropodial hook. A, G, I (Sta. 15, SA-4, Rep 2, USNM 1642573); B-E, H (USNM 1642577); F, holotype (USNM 1642576). Stained with Shirlastain A. 
Pygidium with two short anal cirri (Figs. 1C, 2F-G); one or both sometimes missing, but scars or stubs usually present.

Variability. The most obvious variability among the material is with the beaded or moniliform segments. In some specimens all segments are at least weakly moniliform with anterior segments short and rounded, middle segments elongated and posterior segments again short and rounded. In other specimens the anterior most segments while distinctly separated from one another are weakly crowded, but transition to moniliform segments along most of the body. In other specimens the middle body segments and some posterior segments appear to be stretched or pulled out, thus obscuring the moniliform shape. Finally, the middle segments of other specimens have an intestinal fold that when filled with particles, elevates the dorsum of individual segments thus exaggerating the moniliform appearance.

Methyl Green staining. No pattern.

Remarks. Caulleriella filiformia n. sp. is distinctive among species of Caulleriella in having a long, thin threadlike body with most specimens having moniliform or bead-like segments along nearly the entire length; segments are short and beadlike in anterior and posterior segments, longer in middle segments and stretched, but still weakly moniliform in shape.

Caulleriella filiformia $\mathbf{n}$. sp. is closely related to C. rodmani n. sp. (see below) with which it may occur. In C. filiformia n. sp. the first pair of branchiae arise lateral to the dorsal tentacles on the posterior margin of the peristomium; the second pair and subsequent branchiae occur on setiger 1 dorsal to the notosetae. In contrast, the first pair of branchiae of $C$. rodmani n. sp. arise dorsal to the notosetae on setiger 1. Rounded or moniliform segments typically occur along the entire of body of $C$. filiformia $\mathbf{n}$. sp., while only the first 3-5 thoracic segments of $C$. rodmani $\mathbf{n}$. sp. are rounded. Two short anal cirri occur on the pygidial segment of $C$. filiformia $\mathbf{n}$. sp., whereas the pygidium of $C$. rodmani $\mathbf{n}$. sp. is rounded and lacks anal cirri. One or two of the anal cirri may be damaged or broken, but scars or stubs are usually apparent when stained with Shirlastain A. The bidentate hooks of $C$. filiformia n. sp. have an 'alate' flange on the convex side that forms the apical tooth, whereas in C. rodmani n. sp., there is no flange and the apical tooth emerges directly from the shaft.

Biology and Habitat. One paratype (USNM 1642573) has a few large eggs in posterior parapodia that measure up to $350 \mu \mathrm{m}$ in the longest dimension; the large size suggesting direct development. Sediments associated with Sta. 15, the type locality off Charleston, SC, were sampled on only two surveys (Blake et al. 1987). Samples were collected in water depths of 1944-2003 m: SA-4 (May 1985) and SA-5 (Sep 1985). The sediments consisted of $64.1 \%$ sand and $35.9 \%$ silt + clay on SA-4 and $62.3 \%$ sand and $37.7 \%$ silt + clay on SA-5 (Blake et al. 1987). Thus, the sediments were about 2/3 sand and 1/3 silt + clay. The fauna was dominated by Microrbinia linea Hartman, 1965 a common threadlike orbiniid polychaete that was often the most abundant invertebrate in benthic samples in 2000-3000 m depths throughout U.S. South Atlantic study area (Blake et al. 1987; Blake 2021). Caulleriella filiformia n. sp. ranked sixth out of the 20 most abundant taxa, but comprised only $2.8 \%$ of the total fauna (Blake \& Grassle 1994). Sites off New England where C. filiformia $\mathbf{n}$. sp. was collected were in depths of 2055-2193 m.

Etymology. The epithet filiformia is an adjective derived from the Latin, filum, a thread, in reference to the thin, threadlike body of this species.

Distribution. U.S. Atlantic continental slope, off New England to the Carolinas, 1944-2185 m.

\section{Caulleriella nobska new species}

Figure 3

urn:Isid:zoobank.org:act:5CAAF2EE-99DC-4064-AABD-0C7750F04D49

Material examined. (71 specimens) Northeastern USA, off Nobska Point, Woods Hole, Massachusetts, coll. Oct 1975 , N.J. Maciolek, $41^{\circ} 30.86^{\prime} \mathrm{N}, 70^{\circ} 39.36^{\prime} \mathrm{W}$. ca. 5-10 m, holotype (MCZ 161683), 70 paratypes (MCZ 161684).

Description. A moderately sized species, with long narrow body widest in middle segments; holotype complete, with 88 setigers, $21.5 \mathrm{~mm}$ long, $0.3 \mathrm{~mm}$ wide across anterior setigers, $0.44 \mathrm{~mm}$ wide across middle setigers, narrowing again in posterior setigers. Body rounded dorsally, flattened ventrally with shallow mid-ventral groove extending from peristomium to posterior segments (Fig. 3A). Color in alcohol opaque white to light tan; most specimens with light brown cast in middle segments; some specimens with dark brown spots or short bands in variable patterns along body, but not consistent. 

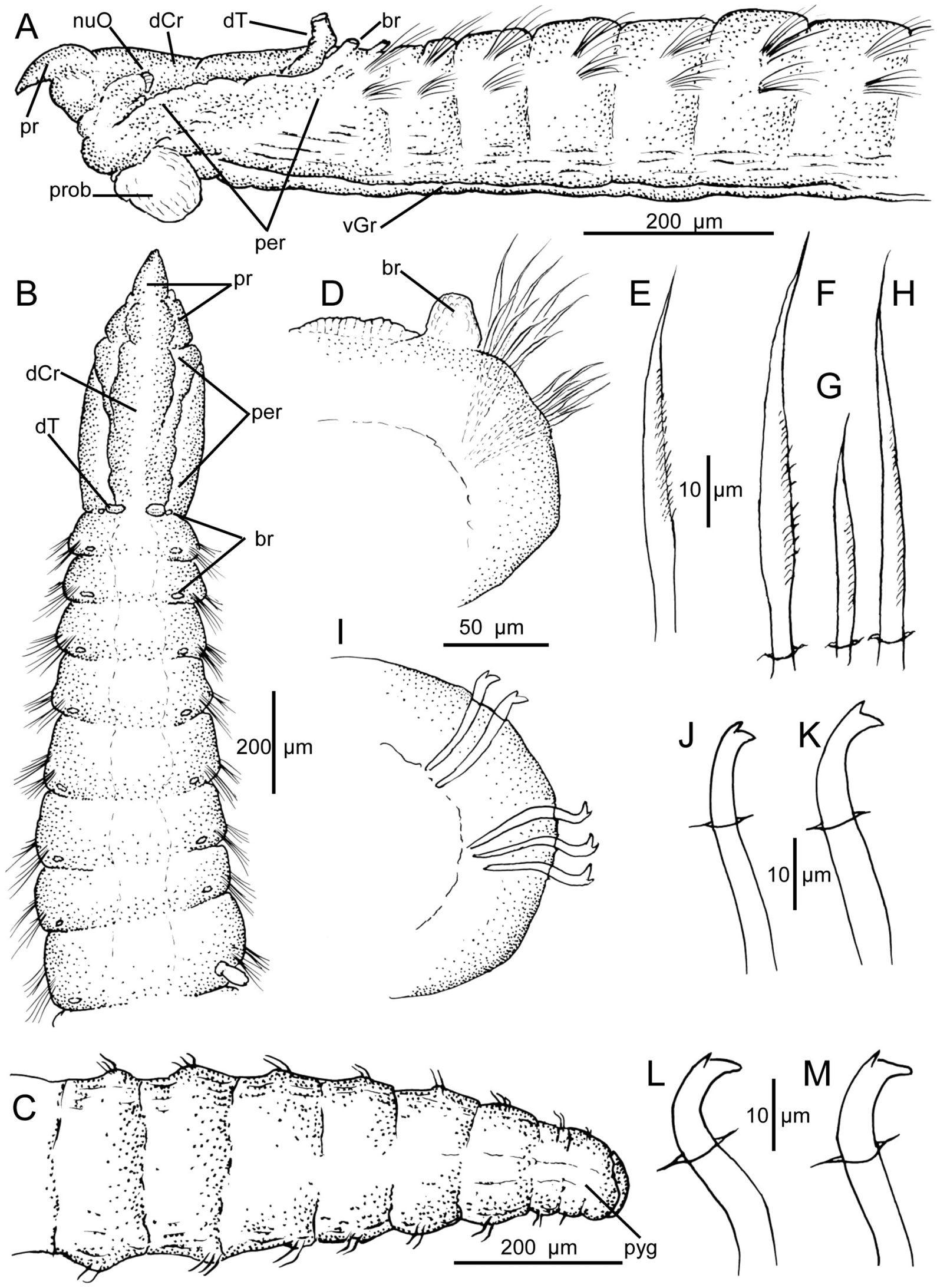

FIGURE 3. Caulleriella nobska n. sp. A, anterior end, left lateral view; B, anterior end, dorsal view; C, posterior end, dorsal view; D, setiger 4, anterior view; E, anterior notopodial capillary seta; F-H, anterior neuropodial capillaries; I, middle body setiger, anterior view; J-K, notopodial bidentate hooks; L-M, neuropodial hooks. A-C, holotype (MCZ 161683); D-M, paratypes (MCZ 161684). 
Pre-setiger region long, narrow, as long as first $3 \frac{1}{2}$ setigers (Fig. 3A-B). Prostomium triangular in dorsal view, tapering to pointed tip (Fig. 3B), relatively narrow in lateral ventral view (Fig. 3A); nuchal organs semicircular grooves on lateral posterior margin; eyespots absent. Peristomium long, narrow, not divided but with well-developed broad dorsal crest (Fig. 3A-B); dorsal tentacles arise from posterior margin (Fig. 3A-B); first branchiae lateral to dorsal tentacles (Fig. 3A-B); second pair of branchiae dorsal to notosetae on setiger 1 and in same location on subsequent setigers (Fig. 3B).

Parapodia reduced, with no distinct podia or postsetal lobes apparent; setae arising directly from body wall. Noto- and neuropodia not widely separated as in related species. Notosetae of first 10-12 setigers all capillaries; hooks first present from setigers 11-13 (13 in holotype). Neurosetae of first 9-10 setigers all capillaries; hooks first present from setigers 10-11 (11 in holotype). Capillaries of both noto- and neuropodia numbering about 8-10 in larger specimens, arranged in two rows with capillaries of first row shorter and thicker than capillaries of second row; notosetae longer than neurosetae (Fig. 3D). Capillaries with broad blades and distinct fimbriated edge with individual fibrils often separated producing the appearance of a serrated edge (Fig. 3E-H). Hooks accompanied by 1-2 capillaries for 1-3 segments, then capillaries entirely absent along body in both noto- and neuropodia (Fig. 3I). Hooks numbering one per noto- or neuropodium through first third of body, then increasing to two and three hooks in middle and posterior setigers. Hooks in noto- and neuropodial fascicles directed toward one another, vis-à-vis (Fig. 3I). Individual hooks with recurved shaft tapering to distinct bidentate apex; main fang directed at about $45^{\circ}$ to shaft with short pointed apical tooth; hood and sheath absent. Hooks of neuropodia appearing slightly thicker and more sigmoidally curved (Fig. 3L-M) than those of notopodia (Fig. 3J-K).

Pygidium with two simple lobes; anal cirri absent (Fig 3C).

Methyl Green staining. No pattern.

Remarks. Unlike most shallow-water species of Caulleriella, C. nobska $\mathbf{n}$. sp. has a long narrow body lacking a distinct separation of the thorax and abdomen. The peristomium is unusually long and bears a prominent dorsal crest. In addition, the noto- and neuropodia are only moderately separated from one another. However, the nature of the recurved bidentate hooks is similar to other species where a hood or sheath is lacking.

Caulleriella nobska $\mathbf{n}$. sp. is most similar to C. venefica, another species from the northeastern United States that is widespread on the continental shelf. Both species have a pointed prostomium, an elongate, smooth peristomium with a dorsal crest, and bidentate hooks lacking a crest or sheath. Caulleriella nobska $\mathbf{n}$. sp. differs from C. venefica in having a shorter prostomium, up to three hooks in posterior neuropodia instead of two, and no anal cirri on the pygidium instead of two cirri. In addition, the bidentate hooks of $C$. venefica as illustrated by Doner \& Blake (2006) and as observed in this study, have the main fang at a more acute angle than the $45^{\circ}$ angle observed in C. nobska $\mathbf{n}$. sp. and $C$. venefica may have a single thin capillary seta accompanying the hooks in middle and posterior setigers instead of capillaries being entirely absent in posterior setigers of $C$. nobska $\mathbf{n}$. sp.

Etymology. The epithet is from the collecting locality off Nobska Point, a promontory in Woods Hole, Massachusetts and the location of a historic lighthouse.

Distribution. Massachusetts, shallow subtidal.

\section{Caulleriella pintada new species}

Figures 4-5

urn:lsid:zoobank.org:act:FE3FC01F-8A0A-4D02-87C0-D31C1DF978F5

Caulleriella sp. 3: Blake et al. 1987: C-2 (in part); Blake \& Grassle, 1994: 854-855; Hilbig 1994: 940 (in part).

Material examined. (83 specimens). Southeastern USA, off Charleston, South Carolina, U.S. South ACSAR Program, J.A. Blake, collector: Sta. 14A: Cruise SA-5, R/V Gyre, Rep. 1, 20 Sep 1985, 32³2.25'N, $77^{\circ} 15.24^{\prime} \mathrm{W}$, $600 \mathrm{~m}$ holotype (USNM 1642599), 40 paratypes (USNM 1642600); Rep. 2, 20 Sep 1985, 32 $32.26^{\prime} \mathrm{N}, 77^{\circ} 15.29^{\prime} \mathrm{W}$, $605 \mathrm{~m}, 21$ paratypes (USNM 1642601); Rep. 3, 20 Sep 1985, 32 $32.22^{\prime} \mathrm{N}, 77^{\circ} 15.31^{\prime} \mathrm{W}, 605 \mathrm{~m}, 20$ paratypes (USNM 1642602).

Description. A moderately large, elongate, threadlike species with body generally narrow throughout (Figs. 4A$\mathrm{B} ; 5 \mathrm{~A}, \mathrm{C}$ ); some groups of anterior setigers variably inflated, but overall consistently narrow throughout, narrowest in far posterior setigers. Holotype complete, $11.2 \mathrm{~mm}$ long, $0.4 \mathrm{~mm}$ wide across anteriormost segments, about 0.2 $\mathrm{mm}$ wide in mid-body and posterior segments, with 67 setigerous segments. Anterior and middle setigers relatively 
short, about twice as wide as long (Fig. 4B); posterior setigers about as wide as long, weakly moniliform (Fig. 5F); some specimens with eggs in middle segments (Fig. 5G). Venter with shallow groove in anterior and middle segments, sometimes outlined with dark pigment (Fig. 4A); dorsal surface rounded throughout. Color in alcohol opaque white to light tan; larger specimens with dark brown to black pigment in variable patterns, sometimes outlining parapodia or ventral groove; pigment intense on some specimens including holotype (Figs. 4A, D, 5A), lighter on others; smallest specimens generally not exhibiting pigment.

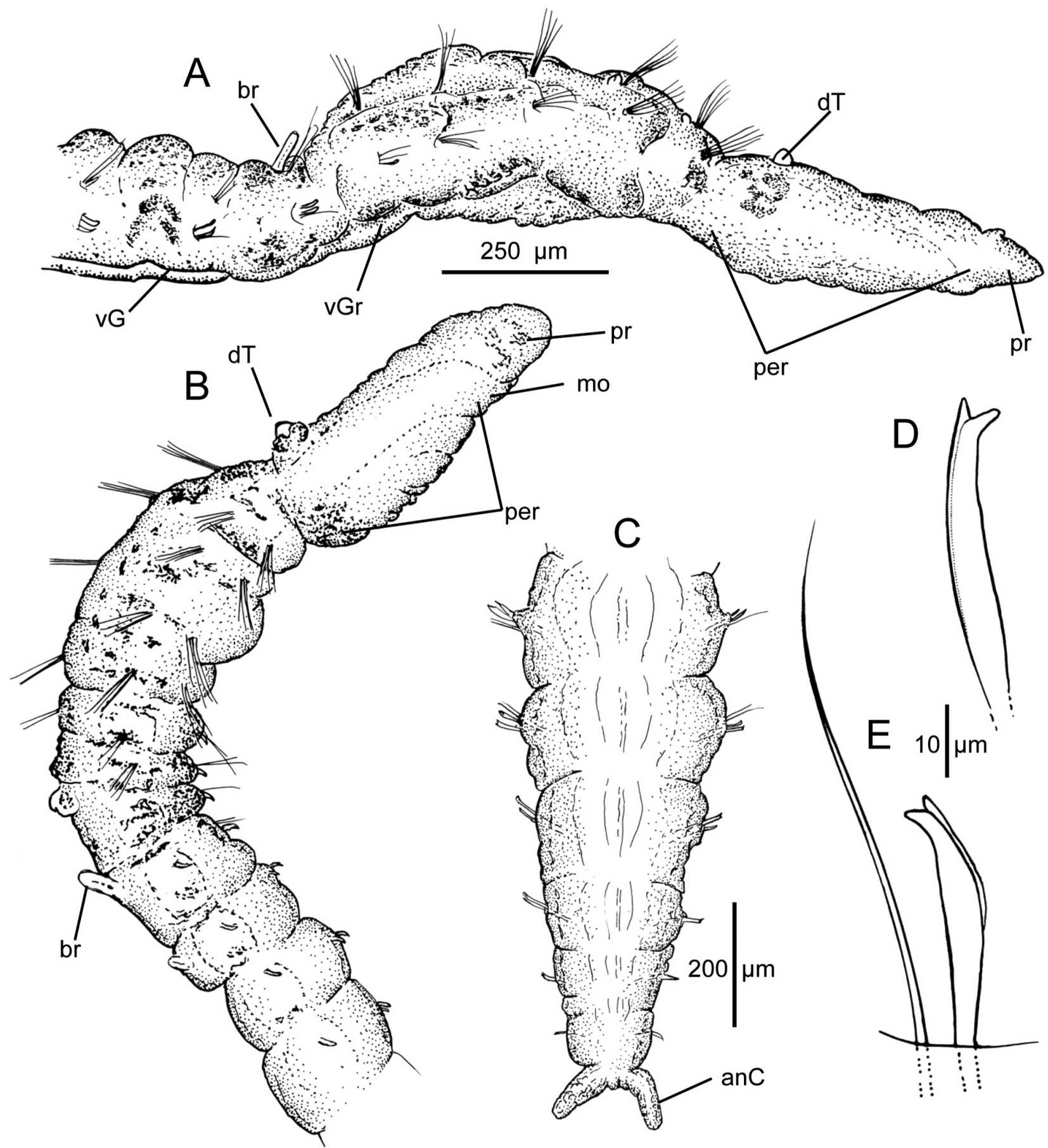

FIGURE 4. Caulleriella pintada n. sp. A, Anterior end, right lateral view; B, anterior end, dorsolateral view; C, posterior end, dorsal view; D, notopodial hook; E, neuropodial hook and capillary. A, C, holotype (USNM 1642599); B, D-E, paratype (USNM 1642600).

Pre-setiger region elongate, cylindrical, up to as long as first five setigers in holotype and largest paratypes (Figs. 4A-B, 5A, C); some specimens with peristomium medially inflated (Fig. 5C-D). Prostomium conical, tapering to bluntly rounded apex (Figs. 4A-B, 5A, C-D); eyespots absent; nuchal organs low mounds at posterior-lateral 


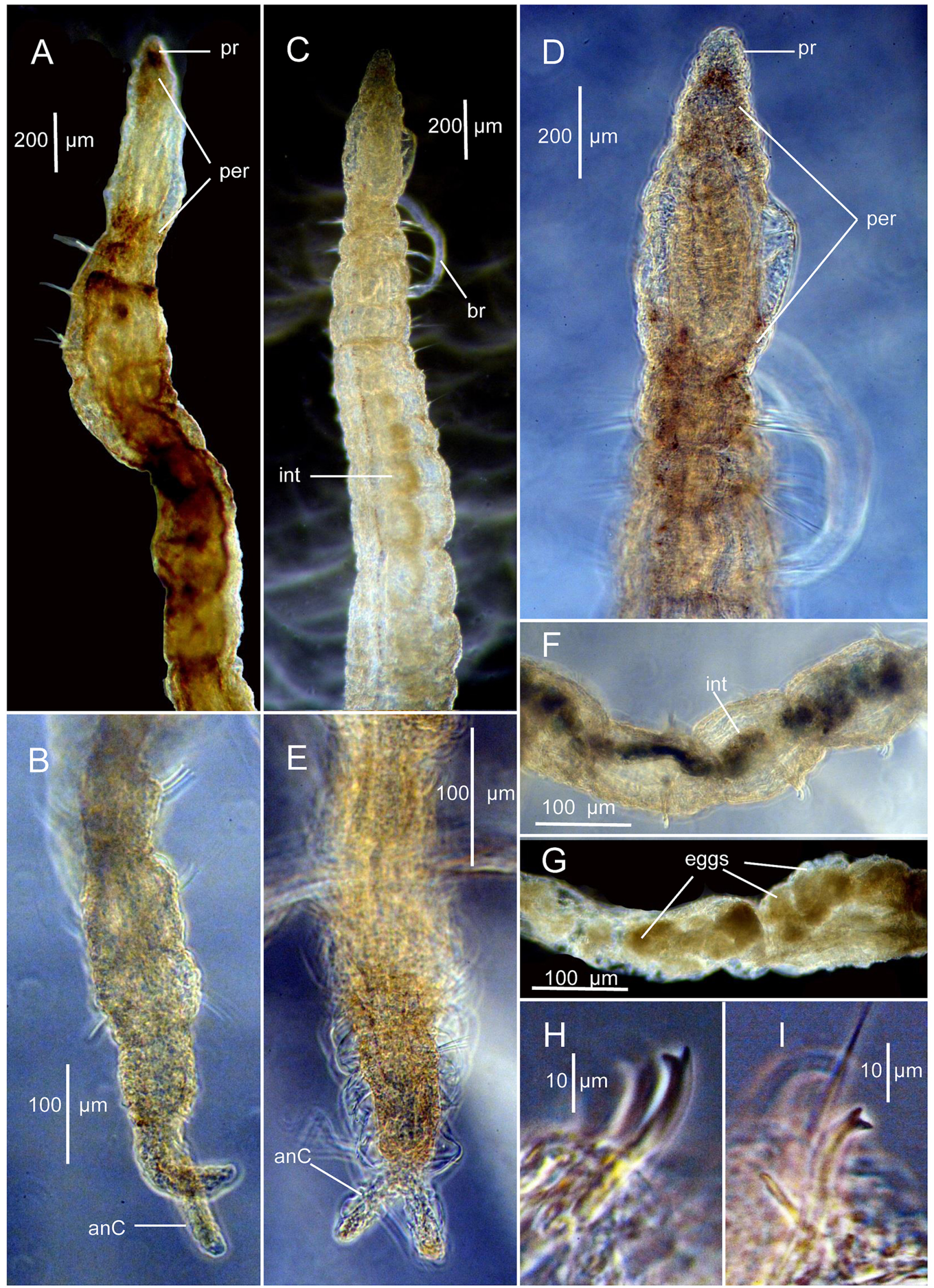

FIGURE 5. Caulleriella pintada n. sp. A, anterior end dorsolateral view; B, posterior end, lateral view; C-D, anterior end dorsal view; E, posterior end dorsal view; F, posterior segments, dorsal view; G, middle body segments with eggs; H, neuropodial hooks; I, notopodial hook and capillary. A-B, holotype (USNM 1642599); C-I, paratypes (USNM 1642600). 
margins prostomium. Peristomium indistinctly separated from prostomium, with no visible annular rings, entire surface smooth, or wrinkled in larger specimens (Figs. 4A-B, 5A, C-D); paired dorsal tentacles arising from near posterior margin (Fig. 4A-B). First branchiae arising dorsal to notosetae on setiger 1; subsequent branchiae in similar position. Most branchiae missing or limited to scars, when retained branchiae long and thin.

Parapodia reduced, weakly developed podia present only in anterior-most setigers, thereafter no podial lobes or lamellae observed, with setae arising directly from body wall. Notosetae of anteriormost setigers with 4-5 capillaries; notoacicular bidentate hooks first present from setiger 8 in holotype; with one hook at first, increasing to two hooks through mid-body segments, usually accompanied by 1-2 thin capillaries; posterior setigers with 2-3 hooks and 1-2 thin capillaries. Neuropodia with 4-5 long capillaries on setigers $1-4$, replaced by bidentate hooks from setiger 5; one hook at first increasing to 2-3 hooks through mid-body segments; with 3-5 hooks in posterior setigers; neuropodial hooks accompanied 1-2 thin capillaries. Hooks in noto- and neuropodial fascicles directed toward one another, vis-à-vis. Individual hooks with relatively thick shaft, weakly curved, tapering to blunt-tipped main fang directed at about $45^{\circ}$ with shaft (Figs. 4D-E, 5H-I); apical tooth smaller, point conforming to curve of shaft, directed forward and appearing to be an extension of an 'alate' flange or hood on the convex side of shaft (Fig. 4D-E). Neuropodial hooks heavier and shorter (Figs. 4E, 5H) than notopodial hooks (Figs. 4D, 5I).

Pygidium a simple lobe bearing two ventral anal cirri (Figs. 4C, 5B, E).

Methyl Green staining. No pattern.

Remarks. Specimens identified as Caulleriella sp. 3 during the ACSAR program actually include two different species: (1) C. pintada n. sp., which appears to be restricted to sandy sediments at $600 \mathrm{~m}$ off South Carolina, and (2) C. filiformia n. sp., which occurred in fine-grained sediments along the $2000 \mathrm{~m}$ isobath off North and South Carolina and off New England.

Caulleriella pintada n. sp. is unusual among species of Caulleriella in the nature of the elongate narrow peristomium that consists of a single ring that is distinctly wrinkled and pigmented in larger specimens. The body has brown to black pigment in variable patterns along the body; this pigment is intense on the holotype and most paratypes. This species, like C. filiformia $\mathbf{n}$. sp., has bidentate setae with an apical tooth that is an extension of an 'alate' hood or flange on the convex side of the shaft, but differs in having the elongate pre-setiger region, branchiae from the posterior margin of the peristomium instead of setiger 1, and distinct pigmentation.

Biology and Habitat. Cruise SA-5, was the only ACSAR survey on which samples were collected at Sta. 14A. The results presented by Blake et al. (1987) and Blake \& Grassle (1994) indicate that Caulleriella pintada $\mathbf{n}$. sp. (as Caulleriella sp. 3) was the most abundant invertebrate species encountered at the site with $14 \%$ of the total number of individuals. The sediment consisted of $94-95 \%$ sand with low water content. The coarse grain size of the sediments at Sta. 14A appears to be important for this species because it was not encountered at other $600 \mathrm{~m}$ stations off Cape Lookout and Cape Hatteras where the sediments have a high silt + clay content. Several paratypes were mature females with eggs about 100-110 $\mu \mathrm{m}$ in diameter (Fig. 5G).

Etymology. The epithet pintada, is from the Spanish pintado, for painted or mottled, referring to the irregular pigmentation patterns found on the larger specimens of this species.

Distribution. Off Charleston, South Carolina, 600-605 m.

\section{Caulleriella rodmani new species}

Figures 6-7

urn:1sid:zoobank.org:act:C4AA5F36-4C99-4055-81C8-96D30D0316AA

Caulleriella sp. 1: Blake et al. 1987: C-2; Maciolek et al.1987a: D-2; Hilbig 1994: 194.

Material Examined. (70 specimens) Off New Jersey and Delaware, U.S. Mid-Atlantic ACSAR program, coll. Rosemarie Petrecca, Chief Scientist. Sta. 5: Cruise Mid-4, Rep. 2, 16 May 1985, 3850.48’N, 72³3.19’W, 2080 m, holotype (USNM 1642603); Rep. 1, 16 May 1985, 38 $50.46^{\prime} \mathrm{N}, 72^{\circ} 33.23^{\prime} \mathrm{W}, 2080 \mathrm{~m}, 2$ paratypes (USNM 1642604); Cruise Mid-1, Rep. 3, May 1984, $38^{\circ} 36.88^{\prime} \mathrm{N}, 72^{\circ} 51.34^{\prime} \mathrm{W}, 2055 \mathrm{~m}$, paratype (USNM 1642605); Cruise Mid-3, Rep. 1, 5 Dec 1984, 3850.42'N, 72 $33.04^{\prime}$ W, 2085 m, (1, USNM 1642606); Cruise Mid-5, Rep. 1, 3 Aug $1985,38^{\circ} 50.44^{\prime} \mathrm{N}, 72^{\circ} 33.18^{\prime} \mathrm{W}, 2077,2$ paratypes (USNM 1642607). Sta. 1: Cruise Mid-2, Rep. 3, 03 Aug 1984,

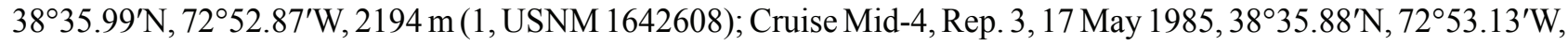
$2195 \mathrm{~m}$, paratype (USNM 1642609). Sta. 2: Cruise Mid-2, Rep. 1, 03 Aug 1984, 38³5.77’ N, 7253.58’ W, $2019 \mathrm{~m}$ 
(1, USNM 1642610); Cruise Mid-3, Rep. 3, 02 Dec 1984, 38³5.68’N, 7253.69’W, 2015 m (3, USNM 1642611). Sta. 4: Cruise Mid-3, Rep. 3, 05 Dec 1983, 38 $44.40^{\prime} \mathrm{N}, 72^{\circ} 41.08^{\prime} \mathrm{W}, 2105 \mathrm{~m}, 2$ paratypes (USNM 1642612); Cruise

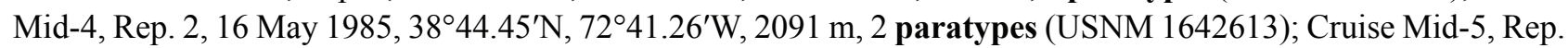
1, 3 Aug 1985, 38 $44.43^{\prime} \mathrm{N}, 72^{\circ} 41.24^{\prime} \mathrm{W}, 2095$ m, paratype (USNM 1642614); Cruise Mid-6, Rep. 3, 11 Nov. 1985, $38^{\circ} 44.40^{\prime} \mathrm{N}, 72^{\circ} 41.26^{\prime} \mathrm{W}, 2105$ m (1, USNM 1642615). Sta. 6: Cruise Mid-3, Rep. 3, 28 Nov 1984, 3905.65'N, $72^{\circ} 03.08^{\prime} \mathrm{W}, 2085$ m, 2 paratypes (USNM 1642616). Sta. 7: Cruise Mid-1, Rep. 3, 06 May 1984, 38 27.30'N, $73^{\circ} 03.43^{\prime} \mathrm{W} .2100$ m, (1, USNM 1642617); Cruise Mid-5, Rep. 2, 07 Aug 1985, 38 $27.32^{\prime} \mathrm{N}, 73^{\circ} 03.54^{\prime} \mathrm{W}, 2095 \mathrm{~m}$,

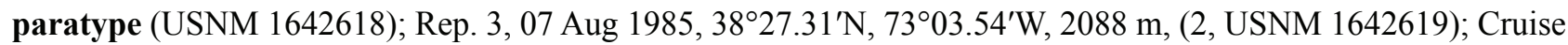

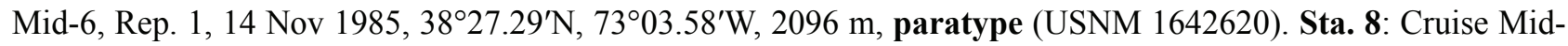

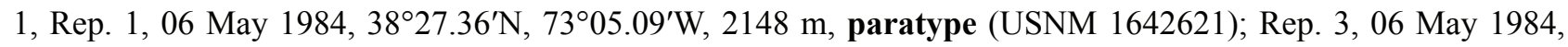
$38^{\circ} 27.36^{\prime} \mathrm{N}, 73^{\circ} 04.81^{\prime} \mathrm{W}, 2150 \mathrm{~m}$, paratype (USNM 1642622); Cruise Mid-2, Rep. 1, 05 Aug 1984, 38 $27.21^{\prime} \mathrm{N}$, $73^{\circ} 04.79^{\prime} \mathrm{W}, 2159 \mathrm{~m}$ (1, USNM 1642623); Cruise Mid-3, Rep. 3, 01 Dec 1984, 38 $27.15^{\prime} \mathrm{N}, 73^{\circ} 04.79^{\prime} \mathrm{W}, 2155$ m, 2 paratypes (USNM 1642624). Sta. 9: Cruise Mid-3, Rep. 1, 30 Nov. 1984, 38 $8^{\circ} 17.20^{\prime} \mathrm{N}, 73^{\circ} 14.38^{\prime} \mathrm{W}, 2110 \mathrm{~m}$ (1, USNM 1642625); Cruise Mid-4, Rep. 2, 18 May 1985, 38 $8^{\circ} 17.20^{\prime} \mathrm{N}, 73^{\circ} 14.65^{\prime} \mathrm{W}, 2105 \mathrm{~m}$, paratype (USNM 1642626). Cruise Mid-5, Rep. 1, 08 Aug 1984, $38^{\circ} 17.24^{\prime} \mathrm{N}, 73^{\circ} 14.63^{\prime} \mathrm{W}, 2100 \mathrm{~m}, 2$ paratypes (USNM 1642627);

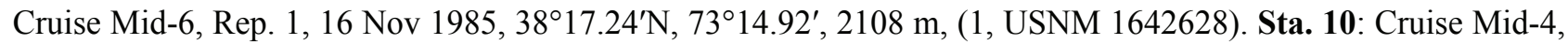

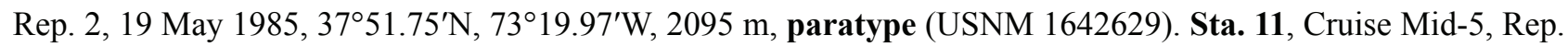
3, 06 Aug 1985, 38 $40.14^{\prime} \mathrm{N}, 72^{\circ} 56.46^{\prime} \mathrm{W}, 1502$ m, (1, USNM 1642630). Sta. 12: Cruise Mid-1, Rep. 1, 8 May 1984, $38^{\circ} 29.34^{\prime} \mathrm{N}, 72^{\circ} 42.23^{\prime} \mathrm{W}, 2501 \mathrm{~m}$, paratype (USNM 1642631); Rep. 2, 8 May $1984,38^{\circ} 29.33^{\prime} \mathrm{N}, 72^{\circ} 42.19^{\prime} \mathrm{W}, 2500$ m, paratype (USNM 1642632); Cruise Mid-6, Rep. 3, 14 Nov. 1985, 38 $29.22^{\prime} \mathrm{N}, 72^{\circ} 42.33^{\prime} \mathrm{W}, 2499 \mathrm{~m}$, paratype (USNM 1642633). - Off New Jersey, U.S. EPA DWD-106 Site Survey, Sta. G, Rep. 3,18 Nov 1985, 3855.60’N, 7202.62'W, 2509 m (2, MCZ 161720). - Off New England, U.S. North Atlantic ACSAR program, coll. G.W. Hampson, Chief Scientist. Sta. 3: Cruise NA-2, Rep. 1, 25 Apr 1985, 41 ${ }^{\circ} 01.38^{\prime} \mathrm{N}, 66^{\circ} 20.18^{\prime} \mathrm{w}, 1340 \mathrm{~m}, 3$ paratypes

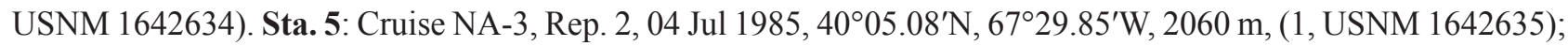
Cruise NA-4, Rep. 1, 25 Nov 1985, 4005.06'N , 67²9.86’ W, 2074 m (1, USNM 1642636); Rep. 3, 25 Nov 1985, $40^{\circ} 05.07^{\prime} \mathrm{N}, 67^{\circ} 29.81^{\prime} \mathrm{W}, 2071 \mathrm{~m}$ (1, USNM 1642637); Cruise NA-5, Rep. 1, 29 Apr 1986, 400․ $00^{\prime} \mathrm{N}, 67^{\circ} 29.94^{\prime} \mathrm{W}$,

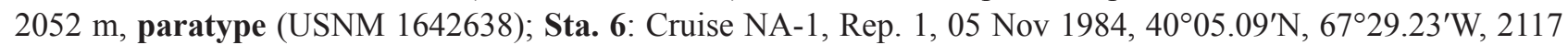
m, paratype (USNM 1642639); Cruise NA-2, Rep. 1, 29 Apr 1985, 400․ $04^{\prime} \mathrm{N}, 67 .{ }^{\circ} 29.99^{\prime} \mathrm{W}, 2108 \mathrm{~m}$, paratype

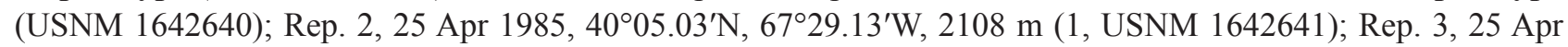
$1985,40^{\circ} 05.06^{\prime} \mathrm{N}, 67^{\circ} 29.13^{\prime} \mathrm{W}, 2107 \mathrm{~m}$, paratype (USNM 1642642). Sta. 8: Cruise NA-1, Rep. 1, 10 Nov 1984, $40^{\circ} 10.37^{\prime} \mathrm{N}, 67^{\circ} 37.43^{\prime} \mathrm{W}, 2175 \mathrm{~m}$, paratype (USNM 1642643); Cruise NA-4, Rep. 1, 25 Nov 1985, 40 ${ }^{\circ} 10.21^{\prime} \mathrm{N}$, $67^{\circ} 37.24^{\prime} \mathrm{W}, 2184 \mathrm{~m}$ (1, USNM 1642644); Cruise NA-5, Rep. 2,25 Nov. 1985, 40 ${ }^{\circ} 10.25^{\prime} \mathrm{N}, 67^{\circ} 37.33^{\prime} \mathrm{W}, 2179$ m (1, USNM 1642645). Sta. 9: Cruise NA-2, Rep. 1, 03 May 1985, 39 $50.43^{\prime} \mathrm{N}, 70^{\circ} 01.58^{\prime} \mathrm{W}, 1235 \mathrm{~m}$ (1, USNM 1642646); Rep. 3, 03 May 1985, 39 ${ }^{\circ} 50.42^{\prime} \mathrm{N}, 70^{\circ} 01.64^{\prime} \mathrm{W}, 1225$ m (1, USNM 1642647). Sta. 10: Cruise NA-1, Rep. 2, 13 Nov $1984,39^{\circ} 48.10^{\prime} \mathrm{N}, 70^{\circ} 05.29^{\prime} \mathrm{W}, 1234 \mathrm{~m}$, paratype (USNM 1642648); Cruise NA-2, Rep. 3, 03

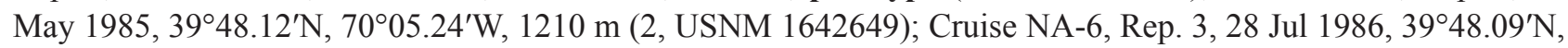
$70^{\circ} 05.29^{\prime} \mathrm{W}, 1228 \mathrm{~m}, 2$ paratypes (USNM 1642650). Sta. 13: Cruise NA-6, Rep. 3, $30 \mathrm{Jul} 1986,39^{\circ} 48.25^{\prime} \mathrm{N}$, $70^{\circ} 54.28^{\prime} \mathrm{W}, 1273 \mathrm{~m}, 2$ paratypes (USNM 1642651). Sta. 14: Cruise NA-2, Rep. 2, 05 May 1985, 3940.93'N,

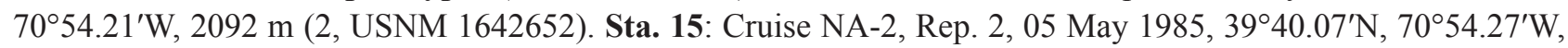
2145 m, 2 paratypes (USNM 1642653); Cruise NA-5, Rep. 3, 06 May 1986, 39 $40.10^{\prime} \mathrm{N}, 70^{\circ} 54.31^{\prime} \mathrm{W}, 2140 \mathrm{~m}$, paratype (USNM 1642654). - Southeastern USA, U.S. South Atlantic ACSAR program, Off Cape Fear, North

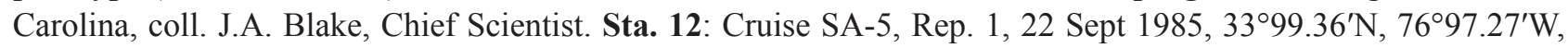
2004 m, paratype (USNM 1642655).

Description. A small, threadlike species; most specimens between 2.5 and $7 \mathrm{~mm}$ long. Holotype complete, 5.15 mm long, $0.07 \mathrm{~mm}$ across peristomium, 0.05 across far posterior setigers, with 24 setigers; large paratype a male, (USNM 1642634) complete in two parts, $7.27 \mathrm{~mm}$ long, $0.12 \mathrm{~mm}$ wide across peristomium, with 31 setigers. First 3-5 segments short, narrow, oval in shape, up to 1.5 times long as wide (Figs. 6A, C, 7A-E); following segments becoming elongated, moniliform, up to three to five times as long as wide (Figs. 6A, C-D, 7A-B); last 2-3 segments narrowing, bearing rounded pygidial lobe (Figs. 6B, 7F). Body generally cylindrical in cross section, no evidence of dorsal or ventral grooves. Color in alcohol; opaque white, with no pigment on body; most specimens with few to many elongate dark fecal masses (pellets) in middle setigers (Fig. 7A-B). 


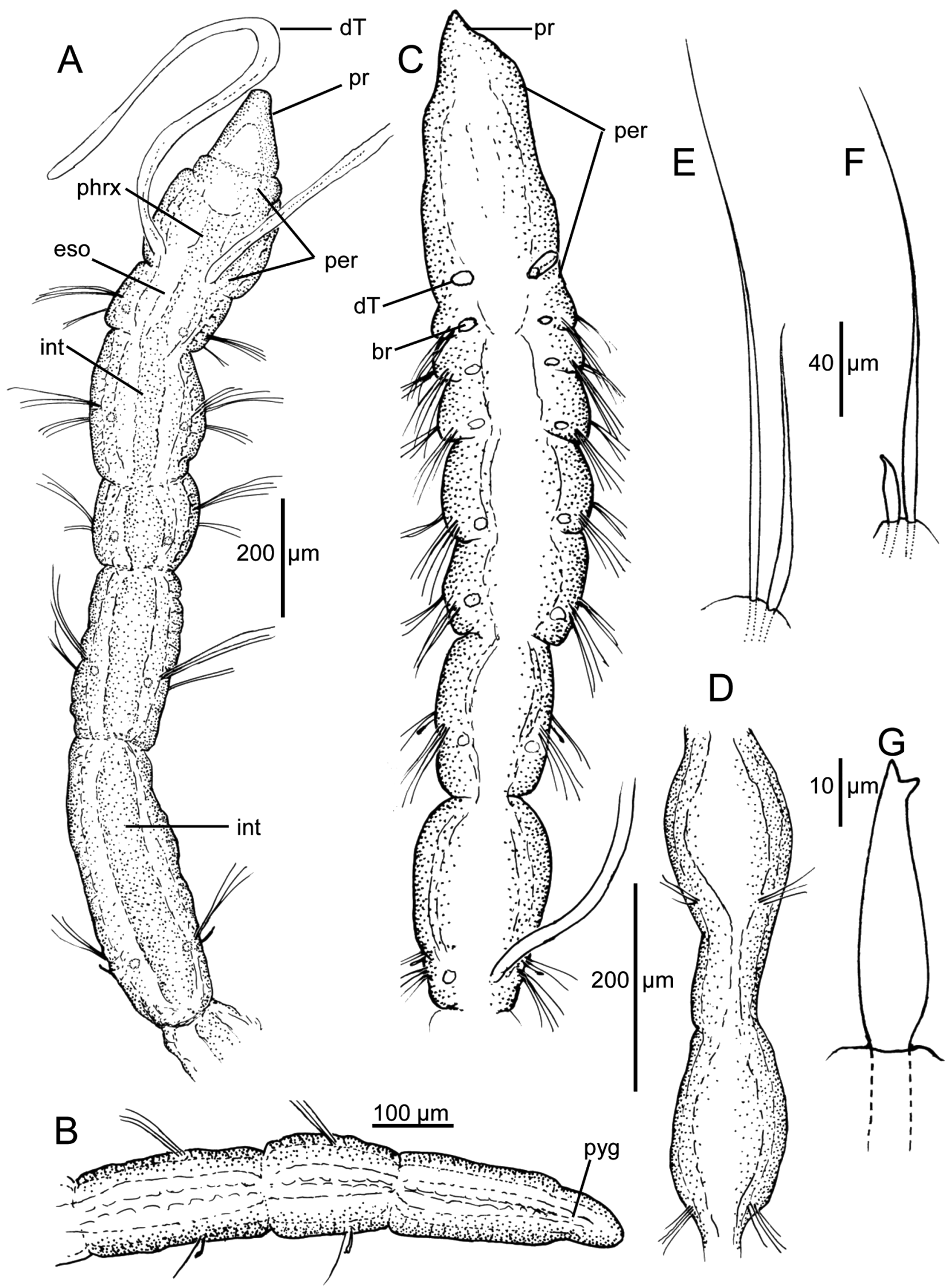

FIGURE 6. Caulleriella rodmani n. sp. A, anterior end, dorsal view; B, posterior end, dorsal view; C. anterior end dorsal view; D, mid-body setigers; E, notopodial capillaries, anterior setigers; F, neuropodial hook and capillary, from anterior setiger 12; G, neuropodial bidentate hook. A-B, holotype (USNM 1642603); C-G, paratype (USNM 1642634). 

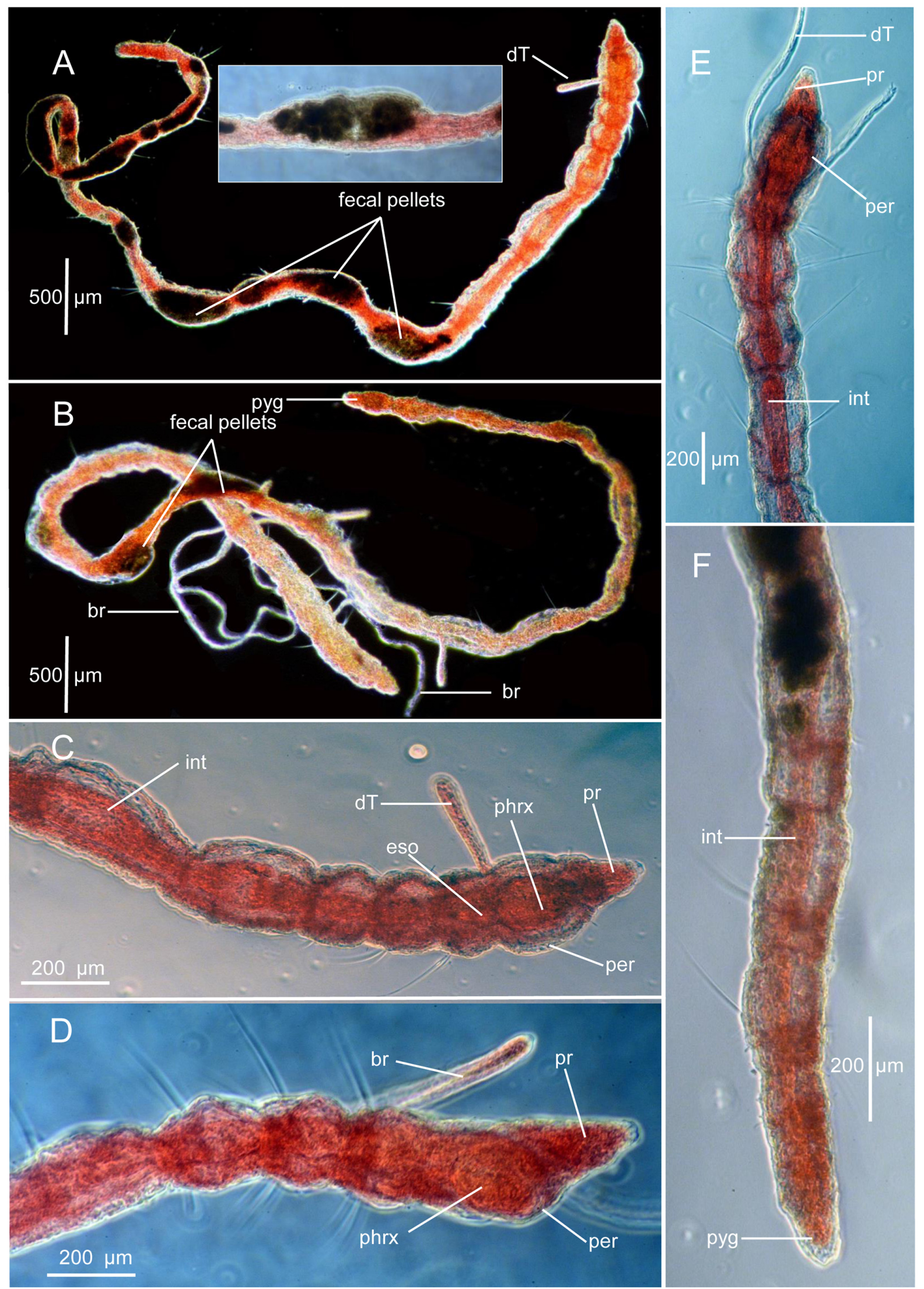

FIGURE 7. Caulleriella rodmani n. sp. A, entire worm, lateral view (inset of segment with fecal pellet not to scale); B, entire worm, dorsolateral view; C, anterior end, right lateral view; D, anterior end, right lateral view; E, anterior end, dorsal view; F, posterior end, dorsal view. A, C, (paratype, USNM 1642648); B, (paratype, USNM 1642633); D-F, holotype (USNM 1542603). 
Pre-setiger region narrow, tapering anteriorly, up to twice as long as wide. Prostomium, triangular, weakly set off from peristomium, conical tapering to narrow, apex (Figs. 6A, C, 7C-E); eyespots absent; nuchal organs narrow slits on posterior lateral margins of prostomium, difficult to observe with light microscope. Peristomium smooth, with no apparent annular rings (Fig. 6A, C). Dorsal tentacles arise from posterior margin of peristomium (Figs. 6A-B, 7A, C, E). First pair of branchiae on setiger 1 dorsal to notosetae (Fig. 6C); subsequent branchiae in same location; branchiae or stubs only rarely observed on small specimens. Dorsal tentacles and branchiae when present long, thin, weakly expanded apically.

Parapodia reduced with setae appearing to arise directly from body wall. Noto- and neuropodia distinctly separated from one another, separation not as wide in anterior segments. Capillaries present throughout; anterior notosetae numbering 3-4 per fascicle, longer than neurosetae, which number 2 or 3 per fascicle. Neuropodial bidentate hooks first present from setiger 3-6; hooks numbering one per fascicle at first, increasing to no more than two hooks over last 10-12 setigers, accompanied by 1-2 capillaries throughout. Notopodial bidentate hooks first present from far posterior setiger 21, with one hook at first, second hook present or absent in posterior-most segments; smallest specimens lacking notopodial hooks. Individual hooks with thickened, weakly curved shaft, tapering to bidentate tip with main fang and apical tooth each about same length (Fig. 6G); hood or sheath absent.

Far posterior segments narrowing to a rounded, bulbous pygidium (Figs. 6B, 7F); anal cirri absent.

Methyl Green staining. No pattern.

Remarks. The majority of 70 specimens identified as C. rodmani n. sp. from the U.S. Atlantic continental slope are small and rarely exceeded more than one specimen per $0.09 \mathrm{~m}^{2}$ box core sample. The specimens are so thin that after being emptied from the sample vials into a clean Stender dish with alcohol, they can often only be located visually after a careful search; if specimens cannot be located, the entire dish needs to be searched using the stereomicroscope; the labels and cotton plugs may also need to be rinsed and examined.

The long, thin, fragile body of this species indicates it is meiofaunal in habitat and that most specimens were likely not retained on the $0.3-\mathrm{mm}$-mesh-sieves used in the ACSAR program. The largest paratype was the only specimen determined to be sexually mature; it is a male with numerous sperm packets in the coelom.

Caulleriella rodmani $\mathbf{n}$. sp. is closely related to C. filiformia $\mathbf{n}$. sp., another threadlike species with which it may occur. In C. rodmani $\mathbf{n}$. sp. the first pair of branchiae arise on setiger 1, dorsal to the notosetae, whereas in $C$. filiformia $\mathbf{n}$. sp. the first branchiae are lateral to the dorsal tentacles on the posterior margin of the peristomium, with the second pair on setiger 1 dorsal to the notosetae. Rounded or moniliform segments typically occur along the entire of body of $C$. filiformia $\mathbf{n}$. sp., while only the first 3-5 thoracic segments of $C$. rodmani $\mathbf{n}$. sp. are rounded. Two short anal cirri occur on the pygidial segment of $C$. filiformia $\mathbf{n}$. sp., whereas the pygidium of $C$. rodmani $\mathbf{n}$. sp. is rounded and lacks anal cirri. In addition, the bidentate hooks of the two species are different. In C. filiformia $\mathbf{n}$. sp. the apical tooth is an extension of an 'alate' hood or flange on the convex side of the shaft, whereas in C. rodmani $\mathbf{n}$. sp., the apical tooth directly emerges from the end of the shaft and is not associated with a hood or flange. The dark elongate fecal pellets found in the intestine on most specimens assist in recognition.

Etymology. This species is named for Dr. James E. Rodman, retired Program Director, Division of Environmental Biology, National Science Foundation. Dr. Rodman initiated the PEET (Partnerships for Enhancement and Expertise in Taxonomy) Program and provided funding to this author for the study of polychaetes and training of students.

Distribution. U.S. Atlantic continental Slope from off New England to North Carolina, 1210-2509 m.

\section{Caulleriella venefica Doner \& Blake, 2006}

Figure 8

Caulleriella B: Maciolek-Blake et al. 1985: B-5.

Caulleriella venefica Doner \& Blake 2006: 66-67, Figs. 1, 5B, E; Blake \& Magalhães 2019: 382-383, Fig. 7.3.1.5.17B.

Material examined. (406 specimens) Northeastern USA. New York, Atlantic Ocean, off Jones Beach, Long Island, coll. I. P. Williams: Sta. 02-1, 27 Aug 2005, 40³2.8921'N, 73²6.7373’W, 53.6 m (50, MCZ 161685); Sta.

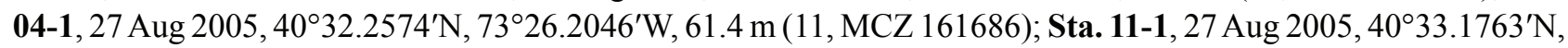

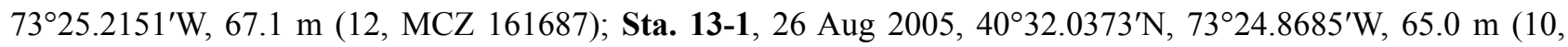
MCZ 161688); Sta. 14-1, 27 Aug 2005, 40³2.8649'N, 73²4.6780’W, 57.9 m (27, MCZ 161689); Sta. 18-1, 27 Aug 2005, $40^{\circ} 34.4606^{\prime} \mathrm{N}, 73^{\circ} 20.5860^{\prime} \mathrm{W}, 62.1 \mathrm{~m}$ (10, MCZ 161690); Sta. 20-1, 26 Aug 2005, 40³2.5438'N, 


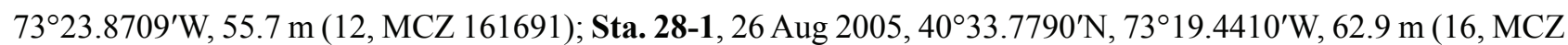
161692); Sta. 29-1, 26 Aug 2005, 40³2.5810’N, 73²2.4412'W, 63.0 m (12, MCZ 161693); Sta. 32-1, 27 Aug 2005,

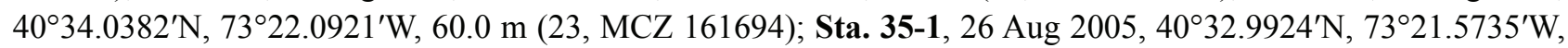
62.9 m (10, MCZ 161695); Sta. 37-1, 26 Aug 2005, 40³3.9938’ N, 73²1.0607’W, 57.9 m (7, MCZ 161696); Sta.

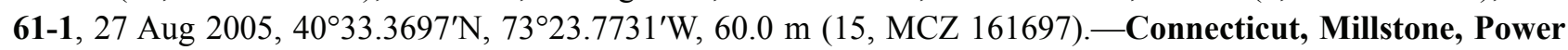
Plant Effluent, coll. Battelle field team, Jun $1979,41^{\circ} 18.48^{\prime} \mathrm{N}, 72^{\circ} 9.96^{\prime} \mathrm{W}, 15-20 \mathrm{~m}$ in sand: sample 1701 (1, MCZ 161698); 1702 (7, MCZ 161699); 1705 (3, MCZ 161700); 1707 (1, MCZ 161701), 1708 (8, MCZ 1617012); 1709 (3, MCZ 161703).—Off Massachusetts, Georges Bank, MMS Benthic Infauna Monitoring Program, coll. G.W. Hampson, Chief Scientist: Sta. 2: Cruise M1, Rep 4, Jul 1981, 4059.0N, 66 ${ }^{\circ} 55.8^{\prime} \mathrm{W}, 79 \mathrm{~m}$ (5, USNM 1642656);

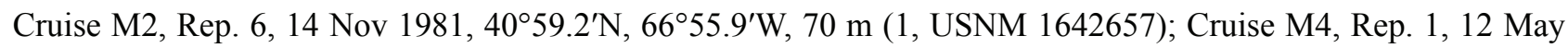
1982, 4059.1'N , 66 $55.9^{\prime} \mathrm{W}, 66$ m (1, USNM 1642658); Rep. 2 (7, USNM 1642659); Rep. 3 (3, USNM 1642660);

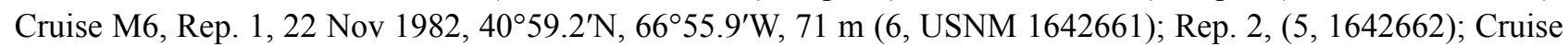
M7, Rep. 1, 07 Feb 1983, 4059.2'N, 66 ${ }^{\circ} 55.9^{\prime} \mathrm{W}, 71$ m (1, USNM 1642663); Rep. 3, (5, USNM 1642664); Rep. 4 (5, USNM 1642665); Rep. 5 (2, USNM 1642666); Rep. 6 (2, USNM 1642667); Cruise M8, Rep. 1, 13 May 1983, $40^{\circ} 59.3^{\prime} \mathrm{N}, 66^{\circ} 55.9^{\prime} \mathrm{W}, 73 \mathrm{~m}$ (1, USNM 1642668); Rep. 3 (1, USNM 1642669); Cruise M9, Rep. 1, 14 Jul 1983, $40^{\circ} 59.2^{\prime} \mathrm{N}, 66^{\circ} 55.8^{\prime} \mathrm{W}, 79$ m (2, USNM 1642670); Rep. 2 (6, USNM 1642671); Rep. 3 (1, USNM 1642672); Rep.

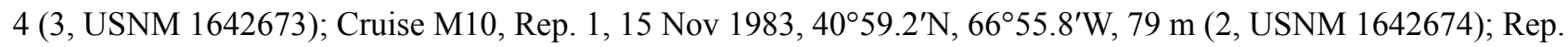

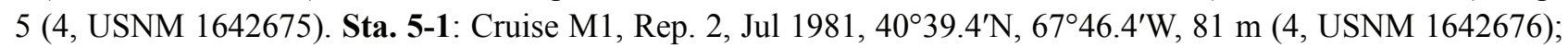
Rep. 3 (3, USNM 1642677); Rep. 5 (2, USNM 1642678); Cruise M2, Rep. 4, 19 Nov 1981, 40 $39.5^{\prime} \mathrm{N}, 67^{\circ} 45.7^{\prime} \mathrm{W}$,

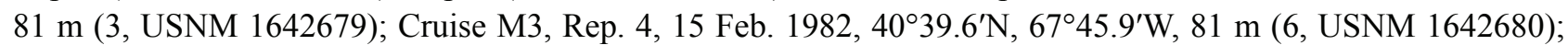

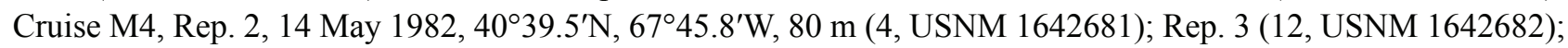

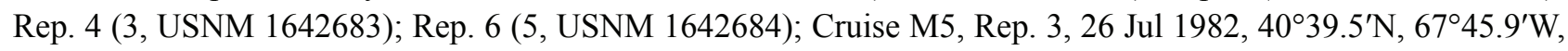
75 m (3, USNM 1642685); Cruise M7, Rep. 2, 10 Feb 1983, 40³9. $5^{\prime} \mathrm{N}, 67^{\circ} 45.9^{\prime} \mathrm{W}, 81 \mathrm{~m}$ (6, USNM 1642686);

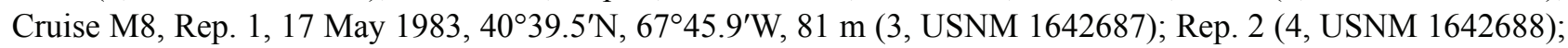
Rep. 4 (5, USNM 1642689); Rep. 5 (5, USNM 1642690); Rep. 6 (3, USNM 1642691); Cruise M9, Rep. 4, 16 Jul

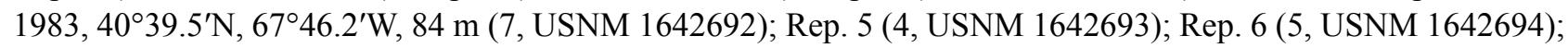
Cruise M10, Rep. 1, 16 Nov 1983, 40 $39.5^{\prime} \mathrm{N}, 67^{\circ} 46.2^{\prime} \mathrm{W}, 84 \mathrm{~m}$ (11, USNM 1642695); Rep. 5 (1, USNM 1642696); Rep. 6 (2, USNM 1642697). Sta. 9: Cruise M10, Rep. 1, 19 Nov 1983, 40²6.7’ N, 6809.8’ W, 144 m (1, USNM 1642698). Sta. 15: Cruise M1, Rep. 4, Jul 1981, 41 ${ }^{\circ} 27.2^{\prime} \mathrm{N}, 68^{\circ} 00.7^{\prime} \mathrm{W}, 37 \mathrm{~m}$ (7, USNM 1642699); Rep. 5 (2, USNM 1642700); Rep. 6 (4, USNM 1642701); Cruise M2, Rep. 1,15 Nov. 1981, $41^{\circ} 27.4^{\prime} \mathrm{N}, 68^{\circ} 00.5^{\prime} \mathrm{W}, 37 \mathrm{~m}$ (1, USNM 1642702); Rep. 2 (2, USNM 1642703); Rep. 3 (1, USNM 1642704). Sta. 16: Cruise M1, Rep. 2, Jul

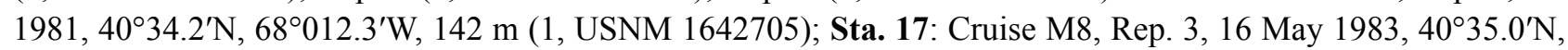
$67^{\circ} 11.3^{\prime} \mathrm{W}, 141 \mathrm{~m}$ (1, USNM 1642706).--Specimens for SEM: Georges Bank Sta. 5-28: Cruise M10, Rep. 4, 13 Nov. $1983,40^{\circ} 39.5^{\prime} \mathrm{N}, 67^{\circ} 41.7^{\prime} \mathrm{W}, 84 \mathrm{~m}$ (4, USNM 1642707).

Description. A moderately-sized species, 11-15 mm long, 0.4-0.5 mm wide for 95-105 setigers. Body long, thickened throughout with narrow, crowded segments. Body dorsoventrally flattened with narrow ventral groove; typically coiled in preservation. Longitudinal muscles apparent along medial dorsal surface. Color in alcohol light tan to brown; no obvious pigmentation except dark internal area in prostomium, possibly indistinct nuchal pigmentation.

Pre-setiger region as long as first eight setigers. Prostomium unusually long, narrow, tapering to pointed tip (Fig. 8A-E); eyes absent; nuchal organs elongate lateral slits on posterior lateral margin. Peristomium enlarged, an achaetous single ring with one or two lateral grooves not crossing dorsum; surmounted by prominent dorsal crest extending from posterior margin of prostomium to setiger 1. Dorsal tentacles arising from posterior margin of peristomium; first pair of branchiae located posterior and lateral to tentacles; second pair of branchiae dorsal to notosetae, continuing throughout. Dorsal tentacles thick with ciliated groove; branchiae long, thin.

Parapodia of anterior setigers reduced to low rounded lobes, becoming low vertical ridges on segments with hooks; noto- and neuropodia widely separated. Notosetae of anterior setigers 4-6 thickened capillaries; bidentate hooks first present from setiger 13-14, with capillaries reduced to a single threadlike seta or entirely absent; up to two hooks per notopodium. Neuropodia with a single bidentate hook from setiger 9-10, increasing to two hooks per fascicle in posterior segments with single threadlike capillary. Hooks of noto- and neuropodia directed toward each other vis-á-vis; hooks with shaft curved on concave side; main fang with apical tooth narrow, short, hood absent (Fig. 8G-H). 

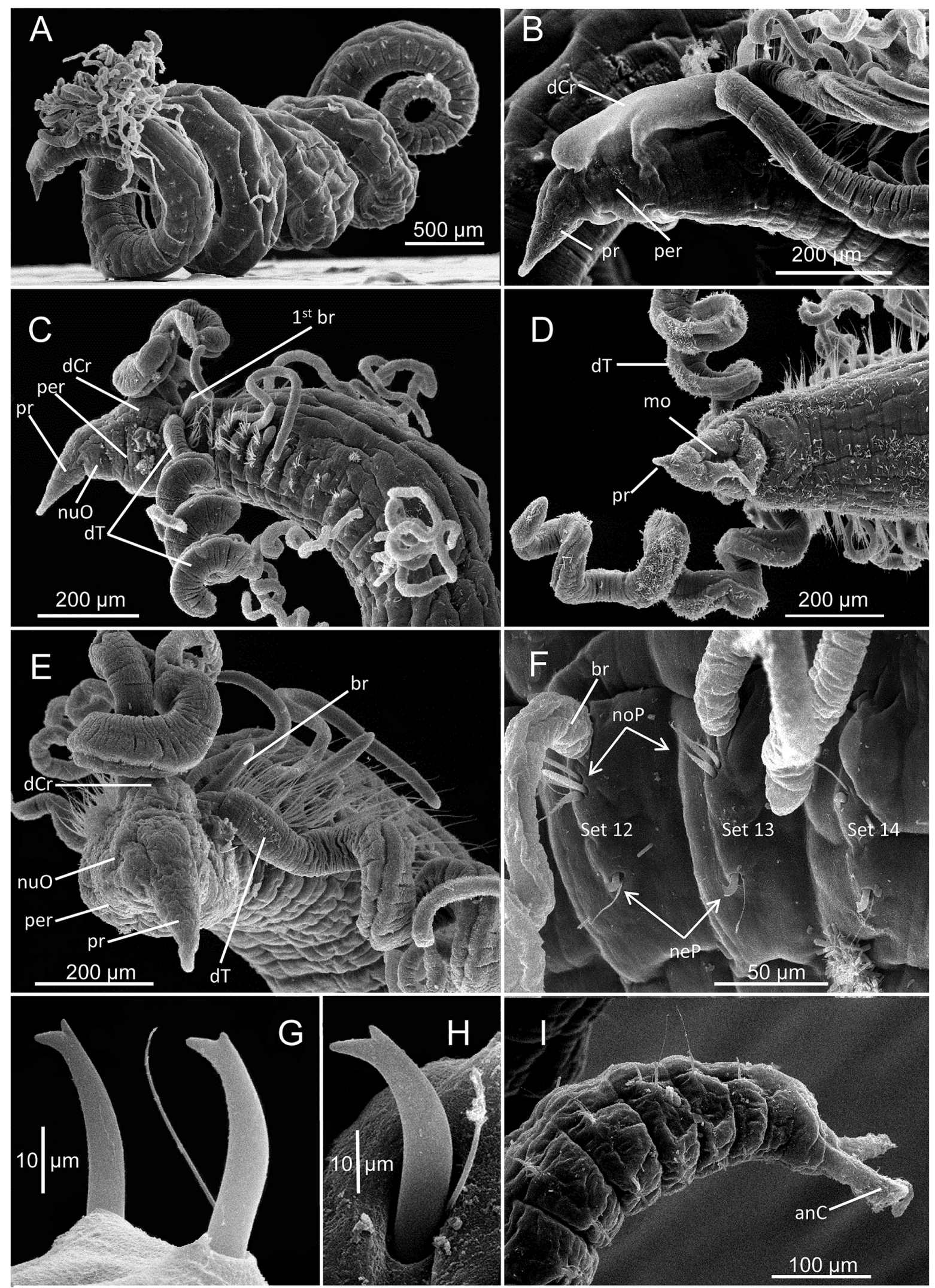

FIGURE 8. Caulleriella venefica Doner \& Blake, 2006. A, Entire worm, coiled; B, anterior end, left lateral view; C, anterior end, left lateral view of another specimen; D, anterior end, ventral view; E, anterior end, frontal view; F, left lateral view of setigers 12-14, noto- and neuropodia with capillaries and hooks evident; G, two neuropodial hooks and one capillary; H, one neuropodial hook and one capillary; I, posterior end, left lateral view. SEMs from three specimens on stub from Georges Bank Sta. 5-28, Cruise M10, Rep. 4, coll. 13 Nov. 1983 (USNM 1642707). 
Posterior end narrow, tapering; pygidium with two short anal cirri (Fig. 8A, I).

Methyl Green staining. Body stains uniformly; anterior half of prostomium not staining.

Remarks. Caulleriella venefica, an offshore shelf species, is most similar locally to C. nobska $\mathbf{n}$. sp., a nearshore species. Both species share a pointed prostomium, an elongate peristomium with a dorsal crest, and bidentate hooks that lack a hood or sheath. However, the prostomium of $C$. venefica is longer, narrower, and more acutely pointed than that of $C$. nobska $\mathbf{n}$. sp. Caulleriella venefica has maximally two instead of three hooks in posterior neuropodia and there are two anal cirri instead of none. In addition, the bidentate hooks of $C$. venefica have the main fang at a more acute angle than the $45^{\circ}$ angle observed in C. nobska n. sp. Caulleriella venefica has a single thin capillary seta accompanying the hooks in middle and posterior setigers instead of these being entirely absent in C. nobska $\mathbf{n}$. sp. The additional records recorded here suggest that the species is widespread throughout the northeastern United States in continental shelf depths having sandy sediments.

Biology and Habitat. On Georges Bank, Caulleriella venefica inhabits sediments having $98-99 \%$ sand, consisting of primarily very coarse to medium-sized sand particles (Maciolek et al. 1985). The long pointed prostomium and narrow elongate body suggest that the species is adapted to burrowing through these larger sediment particles. Other specimens examined as part of this study are also from sediments having high sand inventories.

Distribution. Northeastern US continental shelf, 35-145 m.

\section{Caulleriella sp.}

Material examined. Massachusetts, Cape Cod Bay, off Manomet Point, approximately $41^{\circ} 55.62^{\prime} \mathrm{N}, 70^{\circ} 32.28^{\prime} \mathrm{W}$, among rocks and algal holdfasts, 6-8 m, coll. May 1990, 3 small specimens, one complete (JAB).

Description. The complete specimen from Manomet Point is a small, mature female, with 30 setigers, $1.9 \mathrm{~mm}$ long and $0.25 \mathrm{~mm}$ wide across anterior setigers. All segments are short, not beaded, and with widely separated notoand neuropodia; a ventral groove is present along anterior and middle setigers. In alcohol, the color is opaque white; when stained with Shirlastain A, a prominent internal orange-colored heart body is obvious along the first one-third of the body.

The prostomium is short, tapering to a rounded apex; eyes are absent; nuchal organs were not observed. The peristomium appears to be a single ring, with a distinct dorsal crest. The dorsal tentacles arise from the posterior margin of the peristomium; the first branchiae arise from setiger 1 and continue for about half the length of the body. Notosetae include 2-4 thin capillaries on setigers 1-11, with 1-2 hooks replacing them from setiger 12; neurosetae include capillaries on setigers 1-2, replaced by hooks from setiger 3 with up to 5-6 per fascicle in middle body segments. Hooks bidentate, sigmoid, very small, difficult to study in light microscope possibly 'alate' with narrow flange on curved convex side. Pygidium a rounded lobe, with a least one short anal cirrus present. Eggs are present in setigers $12-18$, at least two per segment, each large relative to the small size of the worm, ca. $85 \mu \mathrm{m}$ in diameter.

Remarks. In May 1990, several small specimens of Caulleriella were collected as part of a monitoring program off Manomet Point, a promontory south of Plymouth, Massachusetts, on Cape Cod Bay. The samples were collected by divers who scraped algae and other encrusting materials from the surface of rocks from a depth of about 6-8 $\mathrm{m}$. At least three different cirratulid polychaetes were identified: Caulleriella sp., Cirratulus sp., and Dodecaceria sp. The short description the Caulleriella specimens allows some comparison with Leidy's (1855) account of C. fragilis from a similar habitat.

History. Caulleriella fragilis was originally described by Leidy (1855) from under intertidal rocks at Point Judith, Rhode Island near the entrance to Narragansett Bay. The species was described as Cirrhatulus [sic] fragilis and was referred to the genus Caulleriella by Chamberlin (1919:372) in a footnote. The species was also recognized as belonging to the genus Caulleriella by Hartman (1944) as part of her publication of Verrill's unpublished plates. Hartman (1959) also listed Caulleriella fragilis in her Catalogue. Despite being the oldest named cirratulid from the U.S. Atlantic coast, $C$. fragilis has rarely been reported and not described since the original report.

Records of Caulleriella fragilis. Leidy (1855: 147) described the species as follows: "Body cylindrical, narrowed towards the extremities, reddish orange color, posteriorly greenish. Mouth inferior, circular; upper lip conical. Eyes two. Cirri numerous, orange colored; the first pair commencing at the second setigerous segment and the most robust. Setae in two rows, simple, in fasciculi of three to five. Podal hooks in two rows, five to eight in each fasciculus, sigmoid, bifid at the free extremity. Intestine cylindrical, constricted. Ovaries on each side of 
the intestine, extending four-fifths the length of the body. Worm three lines long, by one-fourth of line broad and composed of forty annulations. Found under stones, on the shores of Point Judith." Leidy (1855: plate XI, figs. 39-43) illustrates the worm as being long, narrow, and with segments being similar and almost moniliform along the body. The prostomium is large and pear-shaped bearing two large eyespots and followed by a single achaetous segment (peristomium); dorsal tentacles appear to arise on the second setiger, but the points of origin are not indicated. Leidy's (1855) Fig. 43 shows the pygidium as having two rounded lobes and shows a recurved hook with two apical teeth.

The only subsequent reports of the species are by Verrill (1873) from rocky habitats in Vineyard Sound and Webster (1879) from tidal flats of Great Egg Harbor, New Jersey. Verrill (1873: 397) found the species associated with ascidians on rocky and gravelly bottoms. "The Cirrinereis fragilis, which is a small and delicate species, furnished with conspicuous eyes, and related to the large Cirratulus, occurs beneath the stones." Hartman (1944), as part of her unpublished plates by Verrill, assigned Plate 19, fig. 3 to Caulleriella fragilis. This figure illustrates an entire worm in dorsal view and (3a), the same anterior end in ventral view. In this illustration in contrast to that of Leidy, the prostomium is short, conical and bears two small eyespots; this is followed by a peristomium that appears to consist of two rings, the first short and narrow, the second larger which overlaps setiger 1 mid-dorsally. The dorsal tentacles appear to arise from setiger 1 together with the first branchiae. The body segments are short, wider than long. The pygidium consists of a cup-like structure below the anal opening. Setae are not illustrated. This illustration differs from the description and figures of Leidy (1855) in several respects, the most important being differences in the pre-setiger morphology and placement of the dorsal tentacles (setiger 2 in Leidy; setiger 1 in Verrill); as well as different pygidial morphology (two lobes in Leidy and a single cup-like lobe in Verrill).

Webster (1879: 122) identified a specimen as Cirrhinereis fragilis and noted: "Rare; a single injured specimen was found which probably belongs to this species." No further information was presented.

As near as can be determined from the literature and personal communications, there have been no other reports of the species from along the U.S. Atlantic coast and no descriptive remarks since the original account 165 years ago by Leidy (1855). There are no existing specimens of $C$. fragilis from the original collections (M.E. Petersen, in correspondence). The lack of reports of $C$. fragilis are likely due to their cryptic habitat under rocks and nestled among algae and other encrusting organisms. As a result, the identity and status of $C$. fragilis based on differences between the original description and illustrations by Leidy (1855) and notes by Verrill (1873) and illustrations by Verrill published by Hartman (1944) represent a modern-day enigma.

Comparison of the Cape Cod Bay specimens with Caulleriella fragilis. The Cape Cod Bay specimens differ from Leidy's original depiction of $C$. fragilis in several respects. The new specimens have a relatively short, compact body with short crowded segments; the dorsal tentacles arise from the posterior margin of the peristomium; no eyespots are present; and the pygidium consists of a single lobe with at least one anal cirrus. In contrast, the body of $C$. fragilis as illustrated by Leidy (1855) is long and narrow with individual segments mostly as wide as long; the dorsal tentacles were said to arise from setiger 2; a pair of eyespots were present; and the pygidium consisted of two rounded lobes lacking anal cirri. The distinctive color pattern reported by Leidy (1855) was apparently from life, precluding any comparison with the new specimens. Both forms are reported as sexually mature females with eggs. Leidy (1855) was explicit in stating that the first and most robust tentacles began on setiger 2. Such a placement of tentacles has not been recorded in other species of Caulleriella. The absence of eyespots in the Cape Cod Bay specimens may be real or possibly due to fading of the pigments after 30 years in alcohol.

Nevertheless, based on experience of dealing with cirratulids for many years, it is my opinion that the Cape Cod Bay specimens represent a different species than $C$. fragilis as it was originally described and illustrated. The Cape Cod Bay specimens likely represent a species new to science. The placement of the dorsal tentacles, shape of the body, presence or absence of eyespots and pygidial morphology appear to be different between the two forms. The new specimens also differ from Verrill's illustration of $C$. fragilis in Hartman (1944). However, the three Cape Cod Bay specimens are fragile and were damaged with each effort to make observations. For this reason, no effort has been made to formally describe them in this paper. It should be possible, however, to collect additional specimens from rocky habitats along the western side of Cape Cod Bay and perhaps elsewhere in New England. The Cape Cod Bay specimens are therefore, being retained for further study with the expectation that additional materials will be obtained. Hopefully, taking a closer look at the smaller invertebrate fauna encrusting or under intertidal rocks will result in additional specimens of the Cape Bay species as well as determine the identity of C. fragilis. 


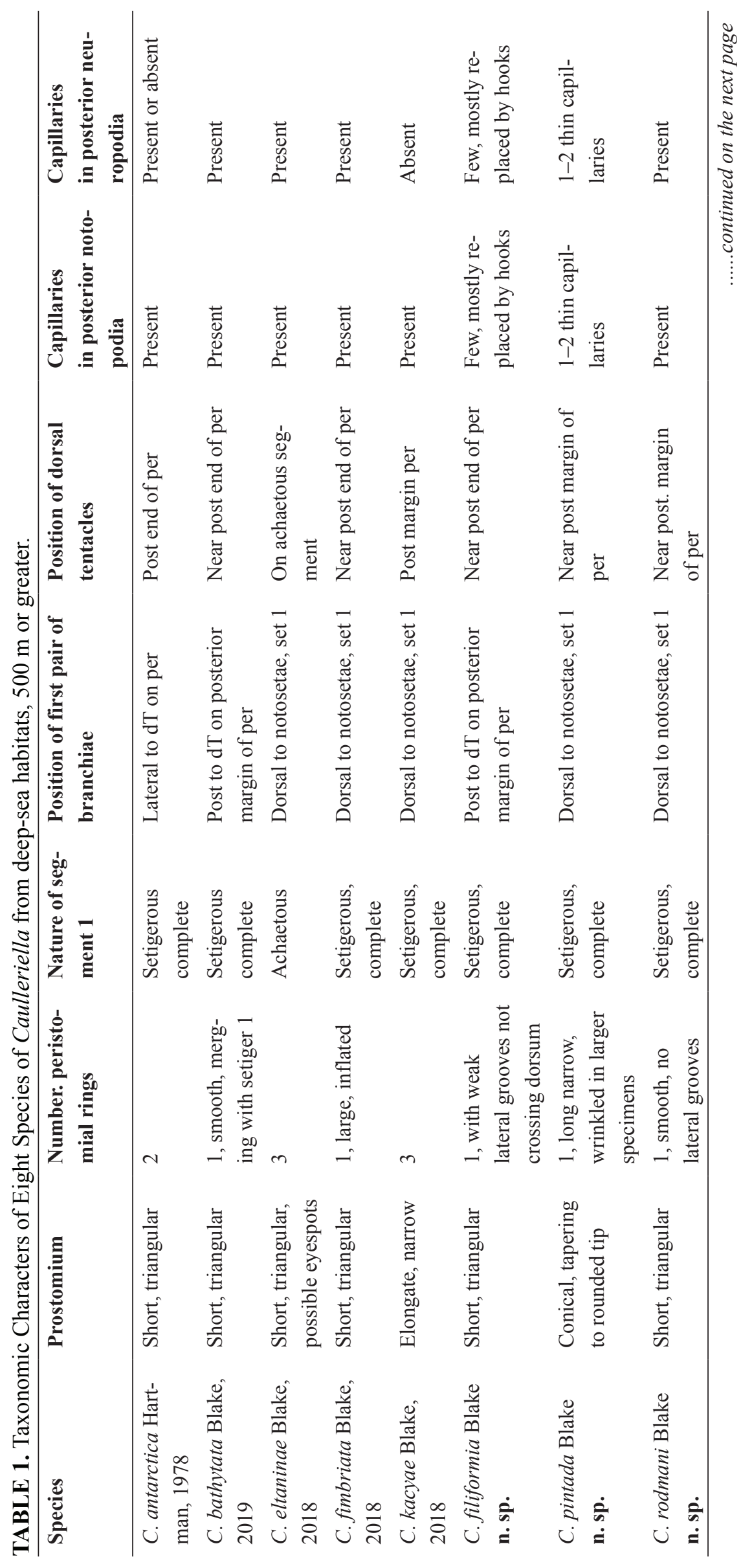

WESTERN NORTH ATLANTIC CAULLERIELLA

Zootaxa 4990 (2) (C) 2021 Magnolia Press · 273 


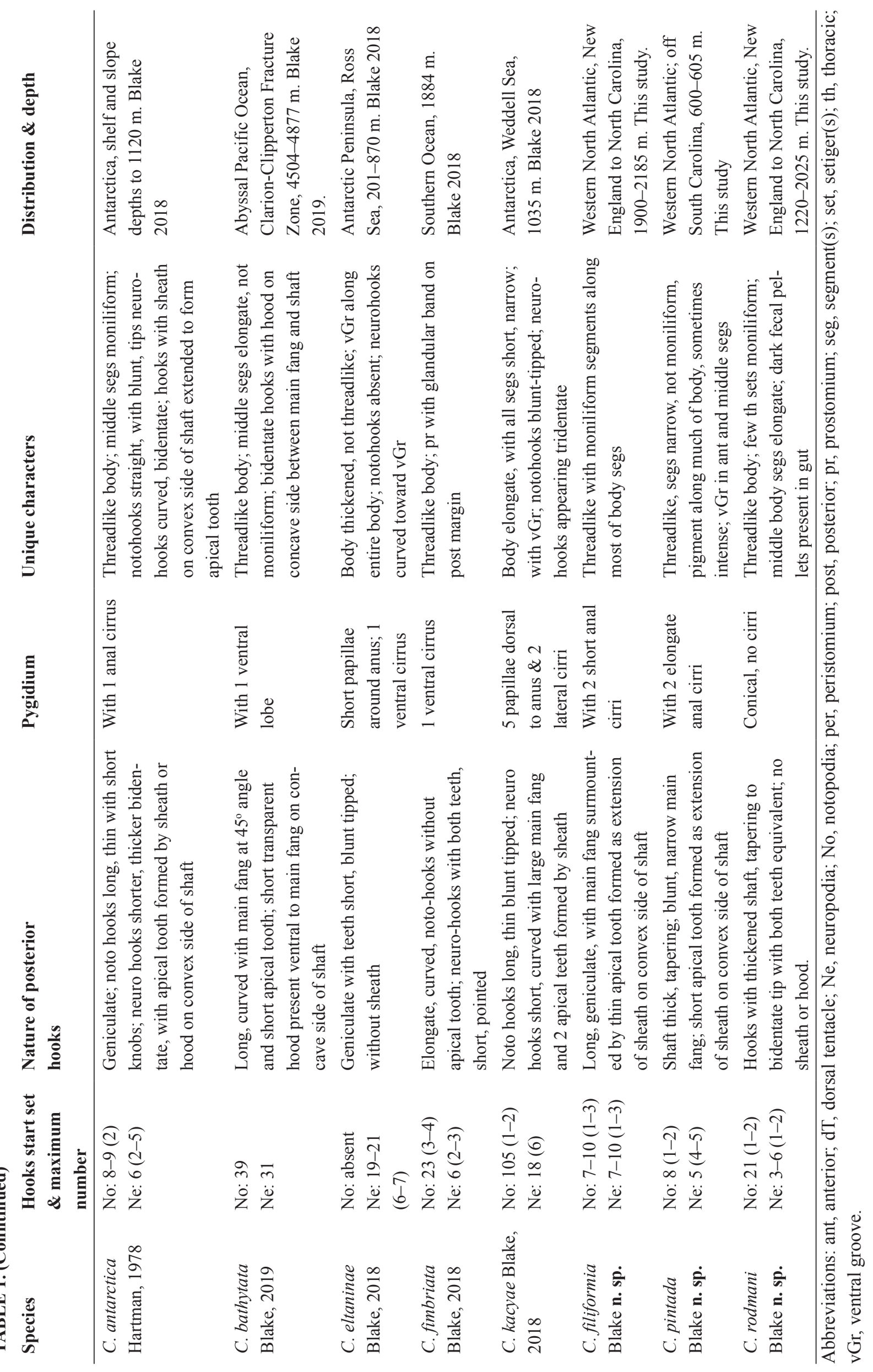




\section{Discussion}

\section{Remarks on the known species of Caulleriella}

Number of valid species. Read \& Fauchald (2021) list 44 valid species of Caulleriella. In addition, Blake \& Magalhães (2019) referred Chaetozone armata Hartman 1963 to Caulleriella. Four additional species described in the present paper bring the total known species of Caulleriella to 49. Of these, 33 species or $67 \%$ were described over the past 25 years. At the same time, another 11 species originally described as Caulleriella were referred to other genera as the definitions of Caulleriella and other bitentaculate genera were redefined (Blake 1991, 1996, 2017). The following is a list of the 49 valid species of Caulleriella with known geography and bathymetry. $(*)=$ species reported with 'alate' hooks.

1. *Caulleriella acicula Day, 1961.South Africa, subtidal.

2. *Caulleriella alata (Southern, 1914) E. North Atlantic, low water.

3. Caulleriella angusticrista Blake \& Dean, 2019. Caribbean Sea, Panama, shallow subtidal.

4. *Caulleriella antarctica Hartman, 1978. Antarctica, deep water 400-1129 m. See Blake 2018.

5. Caulleriella apicula Blake, 1996. Southern California, $24 \mathrm{~m}$.

6. Caulleriella armata (Hartman, 1963). Southern California, 27-180 m. Fide Blake \& Magalhães 2019.

7. Caulleriella bathytata Blake, 2019. Pacific Ocean, abyssal, $4877 \mathrm{~m}$.

8. Caulleriella bioculata (Keferstein, 1862) E. North Atlantic, widely reported.

9. Caulleriella bremecae Elías \& Rivero, 2008. Argentina, intertidal.

10. Caulleriella cabbsi Pocklington \& Coates, 2010. Bermuda, intertidal.

11. Caulleriella capensis (Monro, 1930). South Africa, subtidal.

12. *Caulleriella chilensis Carrasco, 1977. Off Chile, 2-45 m. Fide Blake 2018.

13. Caulleriella convexacapa Blake \& Dean, 2019. Caribbean Sea, Honduras, 10-20 m.

14. Caulleriella cordiformia Magalhães \& Bailey-Brock, 2013. Hawaii, $102 \mathrm{~m}$.

15. Caulleriella cristata Blake, 1996. Central California, intertidal.

16. Caulleriella cucula Dean \& Blake, 2007. Pacific Costa Rica, 9-46 m.

17. Caulleriella dulcensis Dean \& Blake, 2007. Pacific Costa Rica, intertidal.

18. Caulleriella ecuadoriana Blake, 2018. Off Ecuador, 8-20 m.

19. Caulleriella eltaninae Blake, 2018. Antarctica, 210-870 m.

20. *Caulleriella filiformia n. sp. U.S. Atlantic continental slope, off New England to the Carolinas, 1944-2185 m.

21. Caulleriella fimbriata Blake, 2018. Southern Ocean, $1884 \mathrm{~m}$.

22. Caulleriella fragilis (Leidy, 1855). U.S. Atlantic, New England, intertidal in rocks.

23. Caulleriella fucata Blake, 2018. Antarctic Peninsula, 11-12 m.

24. Caulleriella galeanoi Elías \& Rivero, 2008. Argentina, intertidal.

25. Caulleriella glabra Gallardo, 1968. South Vietnam, intertidal.

26. Caulleriella hamata (Hartman, 1948).NE Pacific, Alaska to Washington, intertidal to shallow water.

27. *Caulleriella kacyae Blake, 2018. Weddell Sea, $1035 \mathrm{~m}$.

28. Caulleriella lajolla Blake, 1996. Southern California, in algal holdfasts.

29. Caulleriella magnaoculata Hartmann-Schröder, 1962. Peru, 9 m.

30. Caulleriella mediterranea Lezzi, 2017. Off Italy, $8 \mathrm{~m}$.

31. Caulleriella microbidentata Blake \& Dean, 2019. Caribbean Sea, Honduras, shallow subtidal.

32. Caulleriella minuta Dean \& Blake, 2007. Pacific Costa Rica, intertidal.

33. Caulleriella moralesensis Dean \& Blake, 2007. Pacific Costa Rica, intertidal.

34. Caulleriella murilloi Dean \& Blake, 2007. Pacific Costa Rica, intertidal in mangroves.

35. Caulleriella nobska n. sp. U.S. Atlantic, Massachusetts, shallow subtidal.

36. *Caulleriella pacifica E. Berkeley, 1929. Eastern North Pacific, shallow subtidal.

37. Caulleriella parapicula Blake \& Dean, 2019. Caribbean Sea, Panama, seagrass, intertidal.

38. Caulleriella parva Gillandt, 1979. North Sea, Helgoland, shallow subtidal.

39. Caulleriella parvinasa Blake \& Dean, 2019. Caribbean Sea, Honduras, intertidal in sand.

40. Caulleriella petersenae Díaz-Díaz -, Cardenas-Oliva \& Linero-Arana, 2014. NE Venezuela, shallow subtidal. 
41. *Caulleriella pintada n. sp. Off Charleston, South Carolina, 600-605 m.

42. Caulleriella quadrata Blake \& Dean, 2019. Caribbean Sea, Panama, $5 \mathrm{~m}$ in sand.

43. Caulleriella rodmani n. sp. U.S. Atlantic continental Slope from off New England to North Carolina, 1210$2501 \mathrm{~m}$.

44. Caulleriella suroestense Blake, 2018. Chile, shallow subtidal.

45. *Caulleriella tricapillata Hutchings \& Rainer, 1979. Australia, New South Wales, intertidal.

46. Caulleriella trispina Elías \& Rivero, 2011. Argentina, intertidal.

47. Caulleriella typhlops (Willey, 1905). Indian Ocean, Gulf of Manaar.

48. Caulleriella venefica Doner \& Blake, 2006. U.S. Atlantic, New England, 35-145 m.

49. Caulleriella viridis (Langerhans, 1881). E. North Atlantic, Madeira.

\section{Deep-water species of Caulleriella}

Out of 49 known species of Caulleriella, only eight have been reported from depths of $500 \mathrm{~m}$ and greater, with $C$. bathytata from the abyssal Pacific Ocean in $4877 \mathrm{~m}$ being the deepest species of the genus yet recorded. The eight deep-water species are characterized in Table 1. All of these except $C$. eltaninae have long, threadlike bodies.

\section{Acknowledgements}

Collection and analysis of samples from the Georges Bank Benthic Infauna Monitoring program and Atlantic slope (ACSAR) material included in this paper was made under contract Nos. 14-12-0001-29192 and 14-12-0001-30064 from the Department of the Interior, Minerals Management Service (MMS), to Battelle Ocean Sciences (1983-1987). Elements of these projects were managed by Dr. Nancy J. Maciolek and the author (JAB). Field teams were led by the late Mr. George Hampson (WHOI; Georges Bank and U.S. North Atlantic surveys), Ms. Rosemarie Petrecca (then of WHOI; U.S. Mid-Atlantic surveys), and the author (JAB) (then of Battelle; U.S. South Atlantic surveys). Specimens from off Long Island were collected as part of a proposed wind park project, now defunct; field sampling was directed by Ms. Isabelle P. Williams, a long-time colleague, then of my ENSR Marine \& Coastal Center staff in Woods Hole, MA. Support for completion of this project, including preparation of SEMs of Caulleriella venefica by Dr. Jason Williams Hofstra University, was provided as part of NSF Grant No. DEB-0118693 (PEET) to Dr. J.A. Blake, through the University of Massachusetts, Boston. Curation of the materials used in this study and assignment of catalog numbers was by Ms. Katherine Ahlfeld (USNM) and Ms. Jennifer Trimble (MCZ). Their efforts are appreciated. A draft of the manuscript was read and edited by Dr. Nancy J. Maciolek. Helpful comments by Drs. Harlan K. Dean and Wagner Magalhães were provided during the review process.

\section{References}

Berkeley, E. (1929) Polychaetous annelids from the Nanaimo District. 4. Chaetopteridae to Maldanidae. Contributions to Canadian Biology, Ottawa, New Series, 4, 305-316. https://doi.org/10.1139/f29-022

Blake, J.A. (1991) Revision of some species and genera of Cirratulidae (Polychaeta) from the western North Atlantic. Ophelia Supplement, 5, 17-30.

Blake, J.A. (1996) Chapter 8. Family Cirratulidae. In: Blake, J.A., Hilbig, B. \& Scott, P.H. (Eds.), 1996. Taxonomic Atlas of the Santa Maria Basin and Western Santa Barbara Channel. Vol. 6. Annelida Part 3. Polychaeta: Orbiniidae to Cossuridae. Santa Barbara Museum of Natural History, Santa Barbara, California, pp. 263-384.

Blake, J.A. (2006) New species and records of deep-water Cirratulidae (Polychaeta) from off Northern California. Scientia Marina, 70S3, 45-57. https://doi.org/10.3989/scimar.2006.70s345

Blake, J.A. (2015) New species of Chaetozone and Tharyx (Polychaeta: Cirratulidae) from the Alaskan and Canadian Arctic and the Northeastern Pacific, including a description of the lectotype of Chaetozone setosa Malmgren from Spitsbergen in the Norwegian Arctic. Zootaxa, 3919 (3), 501-552. https://doi.org/10.11646/zootaxa.3919.3.5

Blake, J.A. (2016) Kirkegaardia (Polychaeta: Cirratulidae), new name for Monticellina Laubier, preoccupied in the Rhabdocoela, 
together with new records and descriptions of eight previously known and sixteen new species from the Atlantic, Pacific, and Southern Oceans. Zootaxa, 4166 (1), 1-93.

http://doi.org/10.11646/zootaxa.4166.1.1

Blake, J.A. (2018) Bitentaculate Cirratulidae (Annelida, Polychaeta) collected chiefly during cruises of the R/V Anton Bruun, USNS Eltanin, R/V Hero, RVIB Nathaniel B. Palmer, and R/V Polarstern from the Southern Ocean, Antarctica, and off Western South America. Zootaxa, 4537 (1), 1-130.

https://doi.org/10.11646/zootaxa.4537.1.1

Blake, J.A. (2019) New species of Cirratulidae (Annelida, Polychaeta) from abyssal depths of the Clarion-Clipperton Fracture Zone, North Equatorial Pacific Ocean. Zootaxa, 4629 (2), 151-187.

https://doi.org/10.11646/zootaxa.4629.2.1

Blake, J.A. (2021) New species and records of Orbiniidae (Annelida, Polychaeta) from continental shelf and slope depths of the Western North Atlantic Ocean. Zootaxa, 4930 (1), 1-123.

https://doi.org/10.11646/zootaxa.4630.1.1

Blake, J.A. \& Dean, H.K. (2019) New Species of Cirratulidae (Annelida, Polychaeta) from the Caribbean Sea. Zootaxa, 4671 (3), 301-338.

https://doi.org/10.11646/zootaxa.4671.3.1

Blake, J.A. \& Grassle, J.F. (1994) Benthic community structure in the U.S. South Atlantic off the Carolinas: Spatial heterogeneity in a current-dominated system. Deep-Sea Research II, 41, 835-874.

https://doi.org/10.1016/0967-0645(94)90051-5

Blake, J.A., Hecker, B., Grassle, J.F., Brown, B., Wade, M., Boehm, P., Baptiste, E., Hilbig, B., Maciolek, N., Petrecca, R., Ruff, R.E., Starczak, V. \& Watling, L.E. (1987) Study of Biological Processes on the U.S. South Atlantic Slope and Rise. Phase 2. OCS Study MMS 86-0096: Vol. 2. Final Report. National Technical Information Service (NTIS) No. PB 87-214342 and PB 87-214359. Prepared for the U.S. Department of the Interior, Minerals Management Service, Washington, D.C., ii +414 pp., 13 Appendices. Available from: https://espis.boem.gov/final\%20reports/4698.pdf. (accessed 20 January 2021)

Blake, J.A. \& Magalhães, W. (2019) 7.3.1.5 Cirratulidae, Ryckholt, 1851. In: Purschke, G., Böggemann, M. \& Westheide, W. (Eds.), Handbook of Zoology. Annelida. Vol. 1. Annelida Basal groups and Pleistoannelida, Sedentaria I. De Gruyter, Berlin, pp. 339-397.

Carrasco, F.D. (1977) Polychaeta (Annelida) de Bahia de Concepcion, Chile. Familias Orbiniidae, Cirratulidae, Cossuridae, Capitellidae y Ampharetidae, con la descripcion de tres especies y una subespecie nuevas. Boletín de la Sociedad de Biologia de Concepción, 551, 67-92. Available from: https://www.biodiversitylibrary.org/page/31668336 (accessed 17 September 2019)

Chamberlin, R.V. (1919) The Annelida Polychaeta. Memoirs of the Museum of Comparative Zoology, Harvard, 48, 1-514, pls. 1-80. [http://www.biodiversitylibrary.org/ia/memoirsofmuseumo4801harv]

Day, J.H. (1961) The polychaete fauna of South Africa. Part 6. Sedentary species dredged off Cape coasts with a few new records from the shore. Journal of the Linnean Society of London, 44, 463-560. https://doi.org/10.1111/j.1096-3642.1961.tb01623.x

Dean, H.K. \& Blake, J.A. (2007) Chaetozone and Caulleriella (Polychaeta: Cirratulidae) from the Pacific Coast of Costa Rica, with description of eight new species. Zootaxa, 1451 (1), 41-68.

https://doi.org/10.11646/zootaxa.1451.1.2

Díaz-Díaz, O., Cárdenas-Oliva, A. \& Liñero-Arana, I. (2014) Caulleriella petersenae n. sp. and two new records of Cirratulidae (Annelida: Polychaeta) from Venezuela. Boletin de Investigaciones Marinas y Costeras, 43 (2), 351-361. https://doi.org/10.25268/bimc.invemar.2014.43.2.6

Doner, S.A. \& Blake, J.A. (2006) New species of Cirratulidae (Polychaeta) from the northeastern United States. Scientia Marina, 70 (Supplement 3), 65-73. https://doi.org/10.3989/SCIMAR.2006.70S365

Elías, R. \& Rivero, M.S. (2009) Two new species of Cirratulidae (Annelida: Polychaeta) from Mar del Plata, Argentina (SW Atlantic). Zoosymposia, 2, 139-148. [http://www.mapress.com/zoosymposia/content/2009/v2/index.htm]

Elías, R. \& Rivero, M.S. (2011). A new species of Cirratulidae (Polychaeta) with characteristics of three genera, and a key to the known species around Mar del Plata (south-western Atlantic). Journal of the Marine Biological Association of the United Kingdom, 91, 1529-1535. http://doi.org/10.1017/S0025315410002146

Gallardo, V. (1968) Polychaeta from the Bay of Nha Trang, South Viet Nam. NAGA Report, Scientific Results of Marine Investigations of the South China Sea and the Gulf of Thailand 1959-1961, 4 (3), 35-279.

Gillandt, L. (1979) Zur Systematik, Autökologie und Biologie der Polychaeten des Helogländer Felslitorals. Mitteilungen aus dem Hamburgischen Zoologischen Museum und Institut, 76, 19-73.

Hartman, O. (1944) New England Annelida Part 2 including the unpublished plates by Verrill with reconstructed captions. Bulletin of the American Museum of Natural History, 82 (7), 331-343, pls. 13-35. [http://hdl.handle.net/2246/1052]

Hartman, O. (1948) The polychaetous annelids of Alaska. Pacific Science, 2, 1-58. [http://hdl.handle.net/10125/8890]

Hartman, O. (1963) Submarine canyons of Southern California Part III. Systematics: Polychaetes. Allan Hancock Pacific 
Expeditions, 27 (3), 1-93. [https://www.biodiversitylibrary.org/page/4683347]

Hartman, O. (1965) Deep-water benthic polychaetous annelids off New England to Bermuda and other North Atlantic areas. Allan Hancock Foundation Occasional Paper, 28, 1-378.

Hartman, O. (1978) Polychaeta from the Weddell Sea Quadrant, Antarctica. In: Antarctic Research Series. 26 (4). American Geophysical Union, Washington, D.C., pp. 125-223, 42 figs. https://doi.org/10.1002/9781118664599.ch4

Hartmann-Schröder, G. (1962) Zweiter beitrag zur polychaetenfauna von Peru. Kieler Meeresforschungen, 18, $109-147$.

Hilbig, B. (1994) Faunistic and zoogeographical characterization of the benthic infauna on the Carolina continental slope. DeepSea Research II, 41, 929-950. https://doi.org/10.1016/0967-0645(94)90055-8

Hutchings, P. \& Rainer, S. (1979) The polychaete fauna of Careel Bay, Pittwater, New South Wales, Australia. Journal of Natural History, 13 (6), 745-796. http://doi.org/10.1080/00222937900770561

Keferstein, W. (1862) Untersuchungen über niedere Seethiere. Zeitschrift für Wissenschaftliche Zoologie, 12, 1-147. [https:// www.biodiversitylibrary.org/item/101584\#page/9/mode/1up]

Langerhans, P. (1881) Die Wurmfauna von Madeira. Part III. Zeitschrift für wissenschaftlich Zoologie, Leipzig, 34, 87-143, pls. 4-6. [https://biodiversitylibrary.org/page/42353743]

Leidy, J. (1855) Contributions towards a knowledge of the marine invertebrate fauna, of the coasts of Rhode Island and New Jersey. Journal of the Academy of Natural Science, Philadelphia, 3, 135-152, pls. 9-11. [https://www.biodiversitylibrary. org/page/36848120]

Lezzi, M. (2017) Caulleriella mediterranea, a new species of polychaete (Annelida: Cirratulidae) from the central Mediterranean Sea. The European Zoological Journal, 84 (1), 380-389. https://doi.org/10.1080/24750263.2017.1343397

Maciolek-Blake, N., Grassle, J.F. \& Neff, J.M. (Eds.) (1985) Georges Bank Benthic Infauna Monitoring Program. Final Report for third Year of Sampling. U.S. Department of the Interior, Minerals Management Service, under Contract No. 14-12-000129192. Vol. 2 \& 3. Battelle New England Marine Research Laboratory, Duxbury, Massachusetts, 333 pp. \& Appendices A-K. Available from: https://espis.boem.gov/final\%20reports/4633.pdf \& https://espis.boem.gov/final\%20reports/4634. pdf (accessed 20 January 2021)

Maciolek, N., Grassle, J.F., Hecker, B., Boehm, P.D., Brown, B., Dade, B., Steinhauer, W.G., Baptiste, E. Ruff, R.E. \& Petrecca, R. (1987a) Study of biological processes on the U.S. Mid-Atlantic slope and rise. Final report prepared for the U.S. Department of the Interior, Minerals Management Service, under contract no. 14-12-0001-30064. Vol. 1. Executive Summary \& Vol. 2. Final Report. 44 pp. \& 310 pp., appendices. Available from: https://espis.boem.gov/final\%20reports/4722.pdf (accessed 20 January 2021)

Maciolek, N., Grassle, J.F., Hecker, B., Brown, B., Blake, J.A., Boehm, P.D. Petrecca, R. Duffy, S., Baptiste, E. \& Ruff, R.E. (1987b) Study of biological processes on the U.S. North Atlantic slope and rise. Final report prepared for the Department of the Interior, Minerals Management Service, under contract no. 14-12-0001-30064. Vol. 1. Executive Summary \& Vol. 2. Final Report. 41 pp. \& 362 pp., appendices. Available from: https://espis.boem.gov/final\%20reports/4724.pdf (accessed 20 January 2021)

Magalhães, W.F. \& Bailey-Brock, J.H. (2013) Bitentaculate Cirratulidae (Annelida: Polychaeta) from the northwestern Pacific Islands with description of nine new species. Zootaxa, 3630 (1), 80-116.

https://doi.org/10.11646/zootaxa.3630.1.3

Magalhães, W.F. \& Bailey-Brock, J.H. (2015) A new species and two new records of Cirratulidae (Annelida: Polychaeta) from Guam, Mariana Islands. Journal of the Marine Biological Association of the United Kingdom, 95 (5), 941-46. https://doi.org/10.1017/S0025315414001799

Monro, C.A. (1930) Polychaete worms. Discovery Reports, 2, 1-222, 91 figs. [https://www.biodiversitylibrary.org/ page/15904801]

Pocklington, P. \& Coates, K.A. (2010) Three new species of polychaetes (Annelida: Polychaeta) from Bermuda. Proceedings of the Biological Society of Washington, 123 (3), 220-233. https://doi.org/10.2988/09-24.1

Read, G. \& Fauchald, K. (Ed.) (2020) World Polychaeta database. Caulleriella Chamberlin, 1919. Accessed through: World Register of Marine Species. Available from: http:/www.marinespecies.org/aphia.php?p=taxdetails\&id=129241 (accessed 20 January 2021)

Southern, R. (1914) Claire Island Survey Part 47. Archiannelida and Polychaeta. Proceedings of the Royal Irish Academy, 31 , 1-160, pls. 1-15. [http://biodiversitylibrary.org/page/34773787]

Ryckholt, Philippe de [Baron] (1851) Mélanges paléontologiques. Part 1. Memoires Couronnes et Memoires des Savants Etrangers de l'Academie Royale des Sciences, des Lettres et des Beaux-Arts de Belgique, 24, 1-176, pls. 1-10. [https:// biodiversitylibrary.org/page/2718124]

Verrill, A.E. (1873) Report upon the invertebrate animals of Vineyard Sound and the adjacent waters, with an account of the physical characters of the region. Report of the U.S. Fish Commission for 1871-1872, 1873, 295-852, pls. 1-39. [https:// 
biodiversitylibrary.org/page/12087501]

Webster, H.E. (1879) The Annelida Chaetopoda of New Jersey. Report of the New York State Museum, 32, 101-128. [https:// www.biodiversitylibrary.org/page/35614233]

Willey, A. (1905) Report on the Polychaeta collected by Professor Herdman, at Ceylon in 1902. Ceylon Pearl Oyster Fisheries, Supplemental Report, Part 4, 243-324, pls. 1-8. [https://biodiversitylibrary.org/page/1936112] 